ENVIRONMENTAL

RESTORATION

\author{
PROGRAM
}

Treatability Study for WAG 6 (SWSA 6) Trench Water

\author{
P. A. Taylor
}

MANAGED BY

MARTIN MARIETTA ENERGY SYSTEMS. INC.

FŨT THE UNVITEU STATIES

DEPARTMENT OF ENERGY 
This report has been reproduced directly from the best available copy.

Available to DOE and DOE contractors from the Office of Scientific and Technical Information, P.O. Box 62, Oak Ridge, TN 37831; prices available from 615-576-8401, FTS 626-8401.

Available to the public from the National Technical Information Service, U.S. Department of Commerce, 5285 Port Royal Rd., Springfield, VA 22161. 
Environmental Restoration Division

ORNL Environmental Restoration Program

\title{
Treatability Study for WAG 6 (SWSA 6) Trench Water
}

\author{
P. A. Taylor
}

Manuscript Completed-October 1990

Date Issued-August 1991

Prepared by

Chemical Technology Division

Oak Ridge National Laboratory

Prepared for

U.S. Department of Energy

Office of Environmental Restoration and Waste Management under budget and reporting code GF 72

Oak Ridge National Laboratory

Oak Ridge, Tennessee 37831-6285

operated by

MARTIN MARIETTA ENERGY SYSTEMS, INC.

for the

U.S. DEPARTMENT OF ENERGY

under contract DE-AC05-84OR21400 


\section{Author Affiliation}

P. A. Taylor is a member of the Chemical Technology Division, Oak Ridge National Laboratory, Martin Marietta Energy Systems, Inc. 


\section{CONTENTS}

FIGURES AND TABLES $\ldots \ldots \ldots \ldots \ldots \ldots \ldots \ldots \ldots \ldots \ldots \ldots$

EXECUTIVE SUMMARY $\ldots \ldots \ldots \ldots \ldots \ldots \ldots \ldots \ldots$ vii

1. INTRODUCTION $\ldots \ldots \ldots \ldots \ldots \ldots \ldots \ldots \ldots \ldots \ldots \ldots \ldots \ldots \ldots \ldots$

2. TEST OBJECTIVES $\ldots \ldots \ldots \ldots \ldots \ldots \ldots \ldots \ldots \ldots \ldots \ldots$

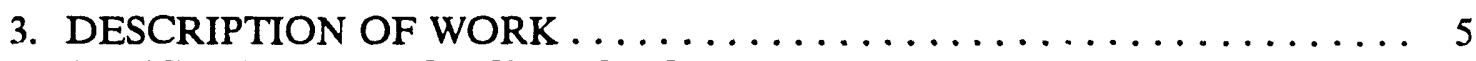

3.1 INITIAL TRENCH SELECTION $\ldots \ldots \ldots \ldots \ldots \ldots \ldots \ldots \ldots \ldots$

3.2 SAMPLING AND ANALYSIS $\ldots \ldots \ldots \ldots \ldots \ldots \ldots \ldots \ldots \ldots \ldots \ldots$

3.3 FINAL TRENCH SELECTION $\ldots \ldots \ldots \ldots \ldots \ldots \ldots \ldots \ldots \ldots$

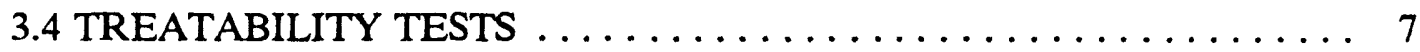

4. MATERIALS AND METHODS $\ldots \ldots \ldots \ldots \ldots \ldots \ldots \ldots \ldots \ldots \ldots$

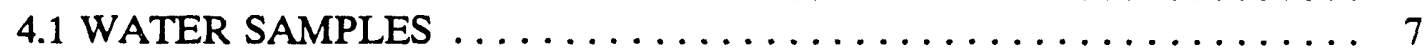

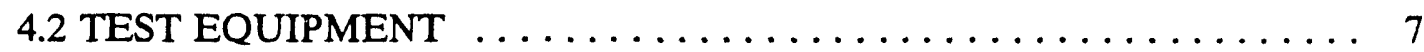

4.3 TEST PROCEDURES $\ldots \ldots \ldots \ldots \ldots \ldots \ldots \ldots \ldots \ldots \ldots \ldots$

4.4 ANALYTICAL METHODS $\ldots \ldots \ldots \ldots \ldots \ldots \ldots \ldots \ldots$

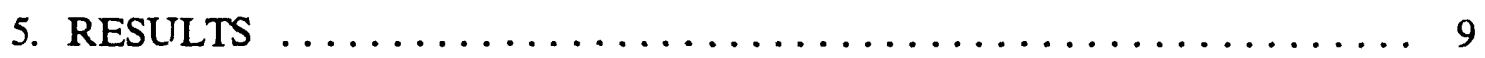

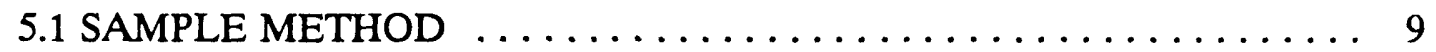

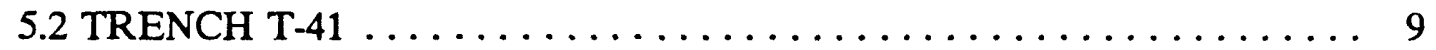

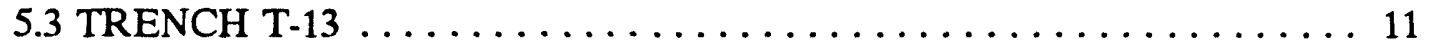

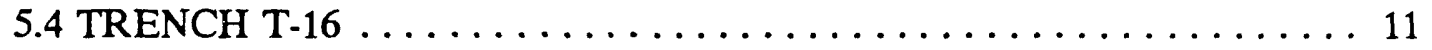

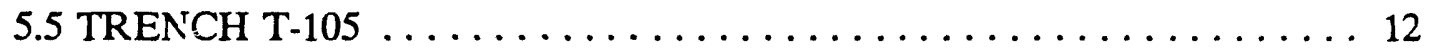

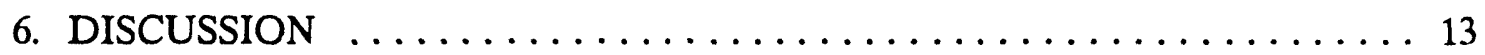

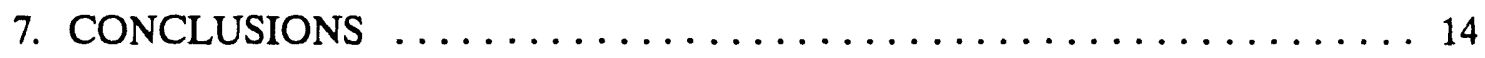

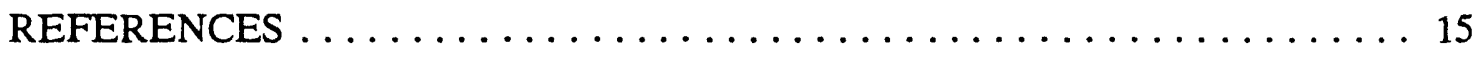

Appendix A. CHEMICAL ANALYSES OF PREVIOUS SAMPLES -

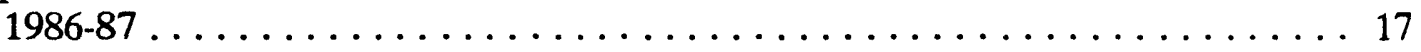

Appendix B. CHEMICAL ANALYSES OF PREVIOUS SAMPLES -

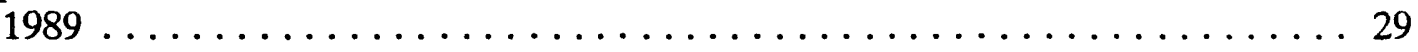

Appendix C. CHEMICAL ANALYSES OF INITIAL SAMPLES . . . . . . . 47

Appendix D. CHEMICAL ANALYSES OF TREATED

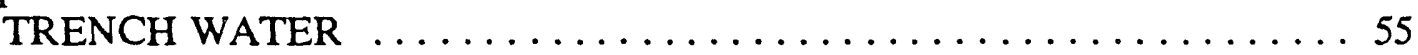




\section{FIGURES}

1 Process wastewater treatment plant (PWTP) $\ldots \ldots \ldots \ldots \ldots \ldots \ldots \ldots \ldots \ldots$

2 Nonradiological wastewater treatment plant (NRWTP) $\ldots \ldots \ldots \ldots \ldots \ldots \ldots$

\section{TABLES}

1 Derived concentration guide values for selected radionuclides (from DOE Order $(5400.5) \ldots \ldots \ldots \ldots \ldots \ldots \ldots$

2 Selected NPDES permit limits for the NRWTP $\ldots \ldots \ldots \ldots \ldots \ldots \ldots \ldots$

3 Results of initial analyses of trench water samples $\ldots \ldots \ldots \ldots \ldots \ldots \ldots$

4 Effect of sampling method on volatile organics $\ldots \ldots \ldots \ldots \ldots \ldots \ldots$

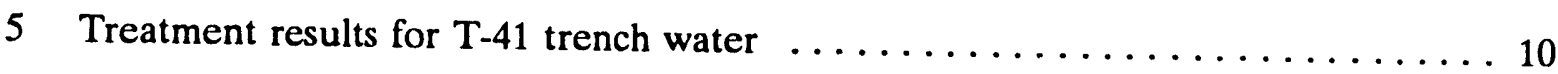

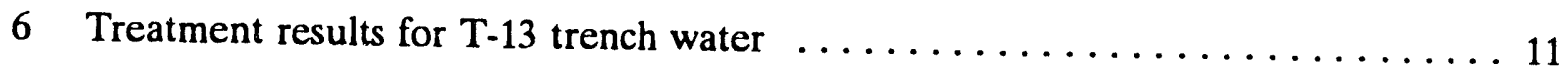

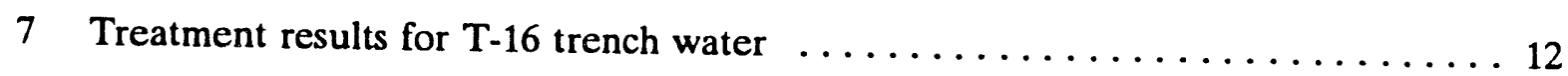

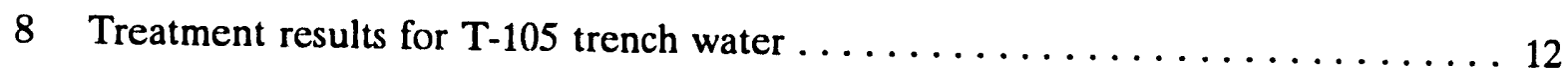

9 Contaminant concentrations in treated trench water $\ldots \ldots \ldots \ldots \ldots \ldots \ldots$ 


\section{EXECUTIVE SUMMARY}

The Environmental Restoration Program at Oak Ridge National Laboratory (OF.NL) is examining methods for remediation and final closure of Waste Area Grouping 6 (WAG 6) under a Resource Conservation and Recovery Act (RCRA) closure plan. WAG 6 consists primarily of Solid Waste Storage Area 6 (SWSA 6), where solid low-level radioactive waste (and some hazardous waste) was buried from 1968 to 1985 in shallow trenches. To support the feasibility study that is being prepared for closure of WAG 6, lab-scale treatability tests were performed on the water from selected trenches in SWSA 6 to determine if the trench water could be treated at the existing wastewater treatment plants at ORNL.

Water from 23 of the 500 trenches in SWSA 6 has been sampled and analyzed to date, and the 4 most highly contaminated trenches identified thus far supplied the water used in the treatability tests. The softening and ion-exchange processes used in the Process Wastewater Treatment Plant (PWTP) reduced the ${ }^{90} \mathrm{Sr}$ concentration, which was the only radionuclide present in the trench water at above the discharge limits, from 260 to $0.2 \mathrm{~Bq} / \mathrm{L}$. The air stripping and activated carbon adsorption processes used in the Nonradiological Wastewater 'Treatment Plant (NRWTP) removed volatile and semivolatile organics (mostly toluene, xylene, and naphthalene), which were the main contaminants in the trench water, to below detection limits. The trench water treated in the lab-scale equipment easily met all discharge limits for the PWTP and the NRWTP. 


\section{INTRODUCTION}

The Environmental Restoration Program at Oak Ridge National Laboratory (ORNL) is examining methods for remediation and final closure of Waste Area Grouping 6 (WAG 6 ) under a Resource Conservation and Recovery Act (RCRA) closure plan. WAG 6 consists primarily of Solid Waste Storage Area 6 (SWSA 6), where solid low-level radioactive waste (and some hazardous waste) was buried from 1968 to 1985 in about 500 shallow trenches. Various technology demonstrations will be conducted on selected trenches at the site during the next few years as part of the feasibility study required by the RCRA closure plan. Some of these demonstrations, and probably the final remediation, will require that the trenches be dewatered. Treatability tests were performed to determine if the water removed from the trenches could be treated at the existing ORNL wastewater treatment facilities.

The ORNL Process Wastewater Treatment Plant (PWTP) treats water that contains very low concentrations of radionuclides-primarily ${ }^{90} \mathrm{Sr}$ and ${ }^{137} \mathrm{Cs}$. The flow sheet for the PWTP is shown in Fig. 1. Most of the calcium and magnesium, and about $70 \%$ of the ${ }^{90} \mathrm{Sr}$, is removed by precipitation at a $\mathrm{pH}$ of 11.5 in the softener. The clarified water is then treated with a strong-acid cation resin (Dowex HCR-S), which removes the remaining ${ }^{90} \mathrm{Sr}$. For the normal PWTP flow rate of $450 \mathrm{~L} / \mathrm{min}(120 \mathrm{gal} / \mathrm{min})$, the empty bed contact time for the water with the resin is $6.2 \mathrm{~min}$. If the water needs to be treated to remove ${ }^{137} \mathrm{Cs}$, then chabazite zeolite columns are used, either in series or parallel with the routine PWTP processes. The discharge requirements for the effluent from the PWTP are listed in DOE Order 5400.5. ${ }^{1}$ Derived Concentration Guide (DCG) values, which are the concentrations below which wastewater does not require treatment, are shown in Table 1 for selected radionuclides. The sludge and spent zeolite produced by the PWTP are currently being stored, pending the development of drying/ solidification processes for the wastes and the startup of new disposal facilities.

Table 1. Derived concentration guide values for selected radionuclides (from DOE Order 5400.5)

\begin{tabular}{cc}
\hline Radionuclide & $\begin{array}{c}\text { Concentration } \\
(\mathrm{Bq} / \mathrm{L})\end{array}$ \\
\hline${ }^{3} \mathrm{H}$ & 74,000 \\
${ }^{60} \mathrm{Co}$ & 185 \\
${ }^{90} \mathrm{Sr}$ & 37 \\
${ }^{137} \mathrm{Cs}$ & 111 \\
\hline
\end{tabular}

${ }^{a}$ Wastewater containing less than the DCG values does not require treatment. 
ORNL OWG 89A-954

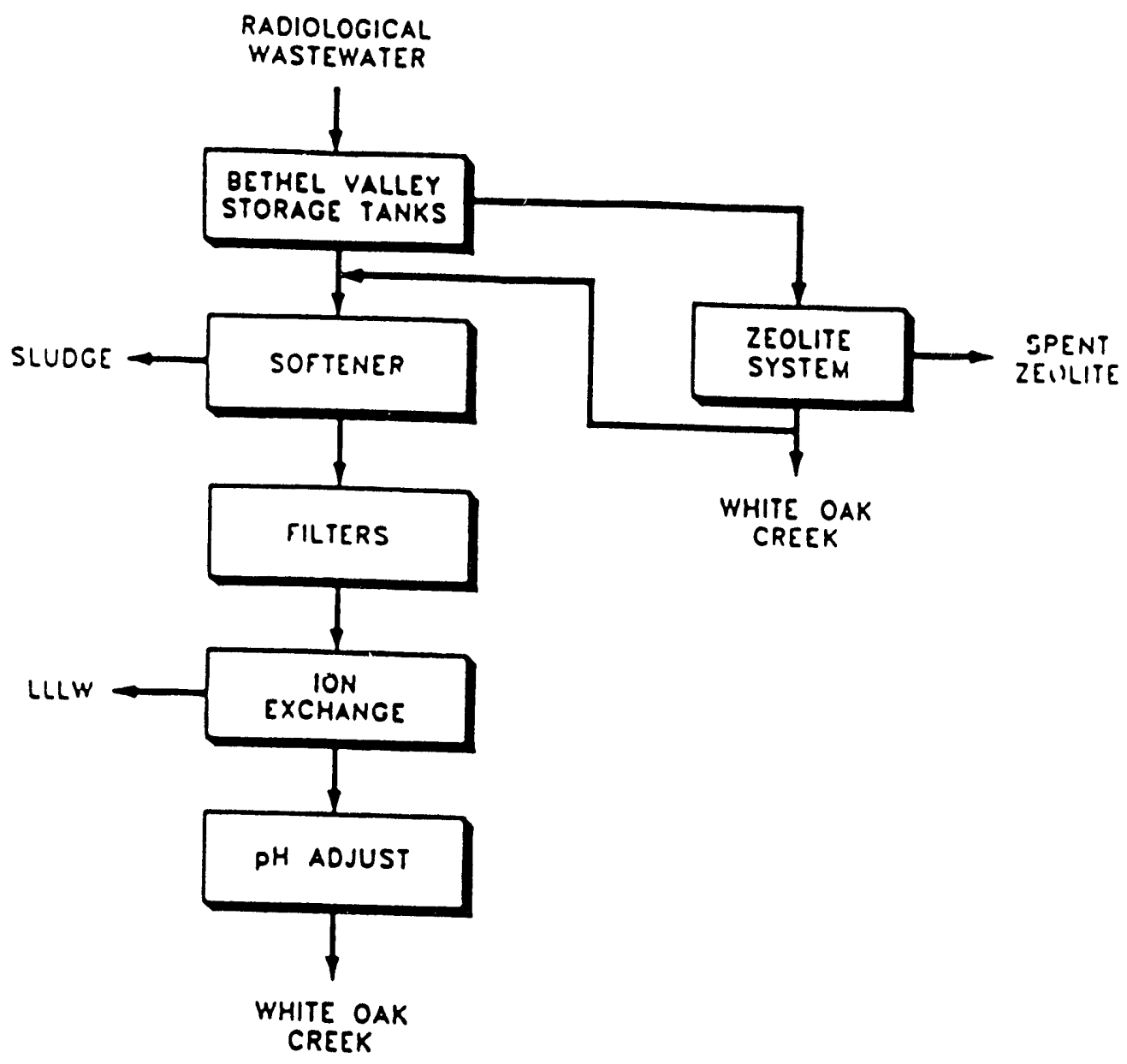

Fig. 1. Process wastewater treatment plant (PWTP). 
The Nonradiological Wastewater Treatment Plant (NRWTP) is a new facility that started operation in March 1990. The flow sheet for this facility is shown in Fig. 2. Most of the wastewater that enters the plant is routed to the nonmetals tank and is treated for organic removal only. The waste acceptance criteria for the NRWTP specifies that the water entering the plant must contain less than the DCG values for all radionuclides. The wastewater flow rate to the plant has averaged $950 \mathrm{~L} / \mathrm{min}(250 \mathrm{gal} / \mathrm{min})$, with a high range of about $1300 \mathrm{~L} / \mathrm{min}(350 \mathrm{gal} / \mathrm{min})$. The air stripper is filled to a height of $6.4 \mathrm{~m}(25 \mathrm{ft})$ with a high efficiency packing (3.5-in. Lanpac, J antec Products, Inc., Agoura Hills, CA). At normal operating conditions, the air stripper has about nine theoretical stages. The carbon columns, which contain about $30,000 \mathrm{~kg}$ of activated carbon (Cecarbon GAC-30, Atochem, Inc.), have an empty bed contact time of $50 \mathrm{~min}$ at a flow rate of $1300 \mathrm{~L} / \mathrm{min}$. The discharge limits for the NRWTP are given in its National Pollutant Discharge Elimination System (NPDES) permit issued by the Tennessee Department of Health and Environment (TDHE). Selected NPDES permit limits are shown in Table 2. The sludge from the NRWTP clarifiers is being stored pending determination of the regulatory status of the waste.

Table 2 Selected NPDES permit limits for NRWTP

\begin{tabular}{lc}
\hline \multicolumn{1}{c}{ Contaminant } & $\begin{array}{c}\text { Daliy maximum } \\
(\mathrm{mg} / \mathrm{L})\end{array}$ \\
\hline Cadmium & 1.20 \\
Chromium & 2.77 \\
Copper & 3.38 \\
Lead & 0.69 \\
Zinc & 2.61 \\
Total toxic organics & 2.13 \\
\hline \multicolumn{2}{c}{${ }^{a}$ See Sect. 4.4. }
\end{tabular}

\section{TEST OBJECTIVES}

The objective of the treatability tests on the WAG 6 trench water was to demonstrate whether the existing wastewater treatment plants at ORNL can effectively treat the WAG 6 irench water to meet the applicable discharge limits. Since the processes used in the treatment plants (precipitation, ion exchange, air stripping, and carbon adsorption) are well known processes for which removal efficiencies can be estimated, the treatability tests focused on identifying possible interferences that might be caused by other contaminants in the trench wate $i$. Contaminants, such as surfactants, can cause foaming in air strippers, and chelating agents can interfere with ion-exchange processes. Because of the difficulty of identifying all of the possible interfering contaminants, treatability tests (rather than analytical analyses) were used to determine if any significant interferences were present in the trench water. 
ORNL DWC 89A-955

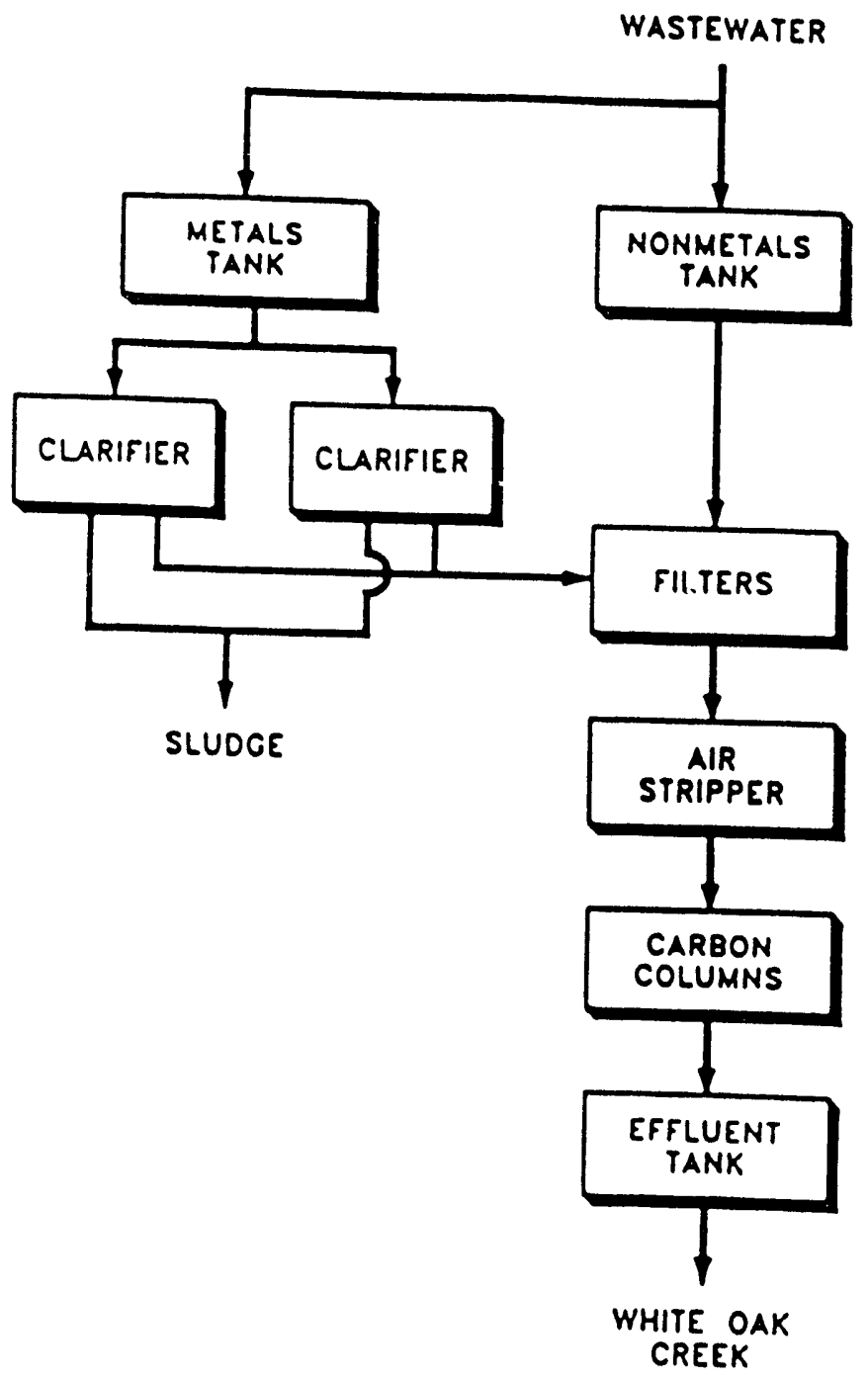

Fig. 2. Nonradiological wastewater treatment plant (NRWTP). 


\section{DESCRIPTION OF WORK}

This task involved: (1) initial selection of the trenches to be examined, based on previous analytical results; (2) sampling of the selected trenches to obtain current contaminant concentrations; (3) selecting four trenches with the highest levels of contaminants; and (4) conducting lab-scale treatability tests on water from these trenches.

\subsection{INITIAL TRENCH SELECTION}

Analytical results are available from two previous sampling programs of trench water at WAG 6. The first was conducted in 1986-87, and involved water from eight trenches ${ }^{2}$ (see Appendix A). The second sampling program was conducted in 1989, and involved water from 15 trenches $^{3}$ (see Appendix B). The 23 trenches that were sampled represent about 5\% of the total number of trenches in SWSA 6. These sampling programs showed that volatile organics (mostly aromatics) are the main contaminants in the trench water. Two trenches (T-41 and T-82) contained ${ }^{90} \mathrm{Sr}$ above the Department of Energy (DOE) discharge limit. None of the trench samples contained heavy metal concentrations above the discharge limits for the NRWTP. Most of the samples also contained tritium; however, no treatment options are currently available for low concentrations of tritium in wastewater, and the average concentrations are below the DOE discharge limits. ${ }^{1}$ Based on the results of these samples, the seven trenches with the highest concentrations of contaminants were selected for further study.

\subsection{SAMPLING AND ANALYSIS}

Analytical samples were obtained from the seven selected trenches using existing shallow wells on November 10,1989. The samples were collected using a vacuum pump to pull the trench water up through teflon tubing directly into the sample bottles, as was done for the previous sampling program. ${ }^{3}$ The samples were analyzed for radionuclides and organics, as described in the Analytical Methods section below. The radionuclide results and selected organic results from these analyses are shown in Table 3, and the full list of organic results is given in Appendix C.

After these samples had been analyzed, water from several trenches around T-13 was sampled by Brian Spalding (Environmental Sciences Division, ORNL) and analyzed for organics in preparation for a remediation test. The water from one of these trenches (T-16) contained high concentrations of volatile organics $(69 \mathrm{mg} / \mathrm{L}$ toluene, $170 \mathrm{mg} / \mathrm{L}$ ethylbenzene, and $77 \mathrm{mg} / \mathrm{L}$ xylene). These results were used, along with the results in Table 3 , in selecting the trenches for the treatability tests. 


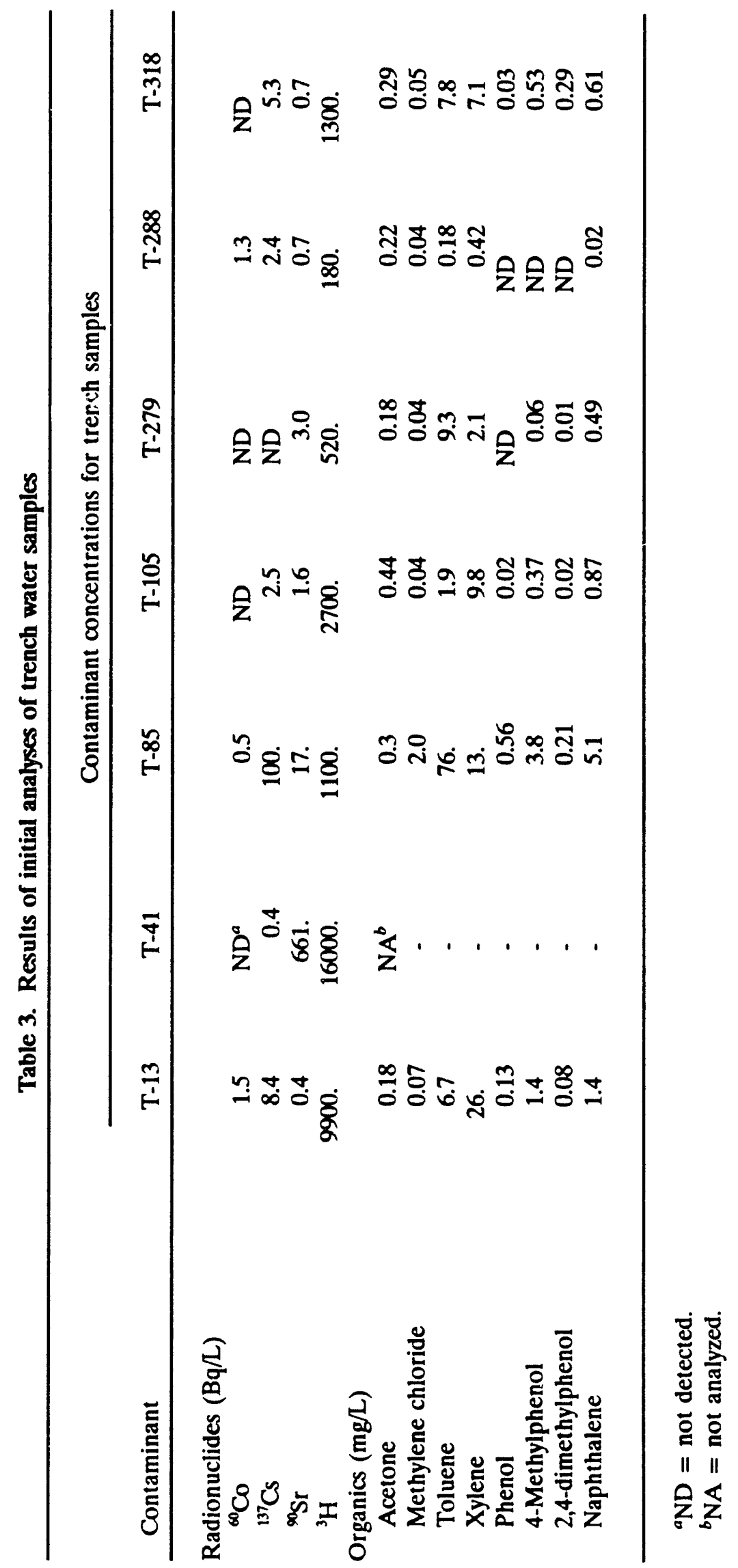




\subsection{FINAL TRENCH SELECTION}

The final selection of the trenches for the treatability tests was made based on the analytical results from the sampling described above. The goal was to select the trenches with the highest concentrations and widest variety of contaminants. The trench with the highest ${ }^{90} \mathrm{Sr}$ concentration (T-41) was selected for the softening and ion-exchange tests. The three trenches with the highest concentrations of organics (T-13, T-16 and T-105) were selected for the air stripping and carbon adsorption tests.

\subsection{TREATABILTYY TESTS}

The treatability tests simulate the processes in the PWTP and NRWTP using fullstrength trench water. Any trench water actually treated at the PWTP or NRWTP will be mixed with a large volume of other wastewater. Also, the trench selection procedure was designed to obtain the most contaminated trench water that had been identified to date (based on sampling 5\% of the trenches), so the treatability tests represent a severe test of the capabilities of the PWTP and NRWTP to treat the trench water.

\section{MATERIALS AND METHODS}

\subsection{WATER SAMPLES}

The water samples for the treatability tests were collected using a vacuum pump to pull the water up through teflon tubing into 4-L amber glass bottles (three bottles per trench). A small sample was collected at the same time using a baler, to determine if any volatile organics were removed by the vacuum pump. Analytical samples were poured from the main sample bottles and from the baler sample within an hour. The bottles for the analytical samples were $40-\mathrm{mL}$ glass vials with teflon lined septums for volatiles, 1-L glass bottles with teflon lined lids for semivolatiles and radionuclides, and $40-\mathrm{mL}$ polyethylene bottles for dissolved metals. The samples for the treatability tests were stored at room temperature until they were used (maximum of 24-h storage time). Trenches T-13 and T-41 were sampled on February 21, 1990, and trenches T-16 and T-105 were sampled on April 30, 1990.

\subsection{TEST EQUIPMENT}

The water softening test was performed in batch mode in a $2-\mathrm{L}$ glass beaker. Whatman \#41 paper was used to filter the decant water. A small ion-exchange column (1.6 cm ID by $20 \mathrm{~cm}$ high) filled to a height of $6.5 \mathrm{~cm}$ with $13 \mathrm{~mL}$ of HCR-S resin was used to model the ion-exchange columns at the PWTP. A column $(9.5 \mathrm{~cm}$ ID by $60 \mathrm{~cm}$ high) filled to a height of $19 \mathrm{~cm}$ with $1.3 \mathrm{~L}$ of chabazite zeolite (TSM-300) was used to model the zeolite columns at the PWTP. 
Because of the large number of theoretical stages in the NRWTP air stripper (about nine for aromatics), it is not practical to construct a laboratory unit to directly simulate this equipment. A small air stripper ( $8 \mathrm{~cm}$ ID by $60 \mathrm{~cm}$ high) filled to a height of $35 \mathrm{~cm}$ with ceramic saddles $(0.6 \mathrm{~cm})$ was constructed. A distributor screen and a packing support were fabricated from stainless steel screen.

Correlations for calculating the height of a theoretical stage are not well established for laboratory-size packings. Sherwood and Hollaways developed correlations for various packings that depend on the liquid density, viscosity, diffusivity and loading rate, and two constants that depend on the size and shape of the packing. Packing constants were available for 1.3-, 2.5- and 5-cm ceramic saddles, but not for the $0.6-\mathrm{cm}$ size used in the laboratory air stripper. For the larger packings, the height of a theoretical stage varied between 46 and 52 $\mathrm{cm}$ for the liquid lnading used in the treatability tests, so assuming that the $0.6-\mathrm{cm}$ packing would have a similar performance to the larger sizes, the laboratory unit should have about $3 / 4$ of a theoretical stage $(35 / 46-3 / 4)$.

The number of theoretical stages for the lab-scale air stripper was also determined experimentally by using pure water saturated with xylene to measure xylene removal, which was compared with that predicted for one theoretical stage. The air stripper reduced the xylene concentration from 40 to $12 \mathrm{mg} / \mathrm{L}$ in one pass. Simulation of the air stripper using the rigorous multistage separation model (RADFRC) in ASPEN (JSD Simulation Service Co., Denver $\mathrm{CO}$ ) predicts that one theoretical stage would reduce the xylene concentration from 40 to $3 \mathrm{mg} / \mathrm{L}$ at the conditions used in the test. Thus, the experimental test also shows that the air stripper has about $3 / 4$ of a theoretical stage $[(40-12) /(40-3)-3 / 4]$.

A column ( $9.5 \mathrm{~cm}$ ID by $60 \mathrm{~cm}$ high) filled to a height of $28 \mathrm{~cm}$ with $2 \mathrm{~L}$ of granular activated carbon (Cecarbon GAC-30, Atochem, Inc.) was used to model the carbon columns in the NRWTP. All of the columns used in the treatability tests have the same aspect ratio (height to diameter ratio) as the corresponding columns in the full-scale treatment plants, and the flow rates for the laboratory units were chosen so that the contact time between the water and the treatment media (ion-exchange resin or activated carbon) was the same as for the full-scale units.

\subsection{TEST PROCEDURES}

A sample of the $\mathrm{T}-41$ trench water was softened at a $\mathrm{pH}$ of 11.5 (using $\mathrm{NaOH}$ ) with $2.5 \mathrm{mg} / \mathrm{L}$ iron (Ferrifloc) and $0.3 \mathrm{mg} / \mathrm{L} \mathrm{Betz} 1100$ polymer added, as is used at the PWTP. The water was stirred gently for $1 \mathrm{~h}$, and then the floc was allowed to settle, and the water was decanted and filtered. The filtered water was processed through the small ion-exchange column at a rate of $2 \mathrm{~mL} / \mathrm{min}$. An unsoftened sample of T-41 trench water was processed through the zeolite column at a rate of $65 \mathrm{~mL} / \mathrm{min}$. Samples of the untreated, softened, ionexchange treated and zeolite treated water were collected for analysis of radionuclides and dissolved metals.

Samples of water from trenches $\mathrm{T}-13, \mathrm{~T}-16$, and $\mathrm{T}-105$ were treated by air stripping and activated carbon adsorption. The bottles of water from each trench were composited into a large glass carboy, leaving the settled solids in the bottom of the bottles. (Note: At the NRWTP, any suspended solids in the wastewater entering the plant are removed in the clarifier and/or the filters.) The water was pumped from the carboy into the top of the air 
stripper at a rate of $400 \mathrm{~mL} / \mathrm{min}$. The air flow rate up through the stripper was $20 \mathrm{~L} / \mathrm{min}$. The temperatures of the air and water entering and leaving the stripper were measured periodically, as was the pressure drop across the column. Samples of the treated and untreated water were collected for volatile and semivolatile analysis. The treated water from the air stripper was then processed through the activated carbon column at a rate of $57 \mathrm{~mL} / \mathrm{min}$. Samples of the activated carbon treated water were collected for analysis of volatiles, semivolatiles, dissolved metals, and radionuclides.

The air stripper and activated carbon column were rinsed with deionized water for at least 5 min following each test so that there would not be any cross contamination between the different trench-water samples during the tests.

\subsection{ANALYTICAL METHODS}

All samples were analyzed at the ORNL Analytical Laboratory, which is qualified under the Environmental Protection Agency (EPA) Contract Laboratory Program. Organics were analyzed with a gas chromatograph-mass spectrometer (GC-MS), using EPA Methods 8240 for volatiles and $\mathbf{8 2 7 0}$ for semivolatiles. The concentration of total toxic organics (TTO) is determined by summing all quantifiable values $>0.01 \mathrm{mg} / \mathrm{L}$ measured in the volatiles and semivolatiles analysis. Samples were analyzed for ${ }^{90} \mathrm{Sr}$ using EPA Method 905.0, tritium was measured by EPA Method 906.0, and a gamma scan (EPA Method 901.1) was used to identify other radionuclides. Dissolved metals were measured using an inductively coupled plasma spectrophotometer (ICP), as prescribed in EPA Method 200.7.

\section{RESULTS}

\subsection{SAMPLE METHOD}

The concentration of volatile organics in the samples taken with a baler are compared to that of the samples taken with a vacuum pump in Table 4. The results show that the vacuum pump did not remove any volatile organics from the samples that were used in the treatability tests.

\subsection{TRENCH T-41}

The radionuclide concentrations of the treated and untreated trench water are shown in Table 5. The untreated water was an opaque brownish-green color with a high concentration of suspended solids. The softening process removed all of the solids, producing clear water for the ion-exchange test. The softening process also removed almost $99 \%$ of the ${ }^{90} \mathrm{Sr}$ in the water, which is better than is typically seen in the PWTP. The ion-exchange resin removed essentially all of the remaining ${ }^{90} \mathrm{Sr}$. The zeolite was also very effective at removing ${ }^{90} \mathrm{Sr}$, and unexpectedly removed $82 \%$ of the tritiated water from the unsoftened trench water. A literature search revealed one other example of concentrating tritiated water with zeolites. ${ }^{6}$ Further tests will be performed on this phenomenon. 
Table 4. Effect of sampling method on volatile organics

\begin{tabular}{llcc}
\hline & \multicolumn{3}{l}{ Volatile organic concentration $(\mathrm{mg} / \mathrm{L})$} \\
\cline { 2 - 4 } Sample description & Acetone & Toluene & Xylene \\
\hline Trench T-13 & & & \\
$\quad$ Vacuum pump & 5.3 & 5.6 & 20 \\
Baler & 3.4 & 3.3 & 21 \\
Trench T-16 & & & \\
$\quad$ Vacuum pump & ND & 47 & 69 \\
Baler & ND & 59 & 70 \\
Trench T-105 & & & \\
Vacuum pump & ND & 40 & 17 \\
Baler & ND & 36 & 16 \\
\hline
\end{tabular}

${ }^{a} \mathrm{ND}=$ not detected.

Table 5. Treatment results for $\mathrm{T}-\mathbf{4 1}$ trench water

\begin{tabular}{lccc}
\hline & \multicolumn{3}{c}{ Contaminant concentration $(\mathrm{Bq} / \mathrm{L})$} \\
\cline { 2 - 4 } Treatment & ${ }^{3} \mathrm{H}$ & ${ }^{90} \mathrm{Sr}$ & ${ }^{137} \mathrm{Cs}$ \\
\hline Untreated & 8,400 & 260 & 0.5 \\
Softened & 8,000 & 3.6 & 0.3 \\
Ion exchange & 7,900 & 0.2 & $<0.1$ \\
Zeolite & 1,500 & $<0.1$ & $<0.2$ \\
$\mathrm{DCG}^{a}$ value & 74,000 & 37 & 111 \\
\hline
\end{tabular}

${ }^{a} \mathrm{DCG}=$ derived concentration guide (see Sect. 1 ). 


\subsection{TRENCH T-13}

The concentration of volatile organics in the water entering the air stripper was much lower than that measured at the time the samples were collected (compare Tables 4 and 6). Apparently, storing the trench water for about $20 \mathrm{~h}$ and/or transferring it into the open carboy was sufficient to strip most of the volatile organics from the water, although this did not happen with the water from the other trenches. The water entering the air stripper was still an opaque brownish-green color, even though the heavier solids had been left in the original sample bottles. After air stripping, the water was a brownish-orange color, from the oxidation of ferrous ions into ferric hydroxide. The water temperature entering and exiting the air stripper was $19^{\circ} \mathrm{C}$, and the air temperature decreased from 23 to $22^{\circ} \mathrm{C}$ through the stripper. The pressure drop across the column varied from 15 to $17 \mathrm{~Pa}\left(0.6\right.$ to 0.7 in. $\left.\mathrm{H}_{2} \mathrm{O}\right)$. There was not any visible foaming in the air stripper. Two samples of treated and untreated water were collected for volatiles analysis, and one sample of each for semivolatiles. The effluent from the activated carbon column, which was crystal clear, was sampled twice for volatiles and once for semivolatiles, dissolved metals, and radionuclides. All of the organic results are shown in Table 6, and the results for the other analyses are shown in Table 9.

Table 6. Treatment results for $\mathrm{T}-13$ trench water

\begin{tabular}{|c|c|c|c|}
\hline \multirow[b]{2}{*}{ Contaminant } & \multicolumn{3}{|c|}{ Contaminant concentration $(\mathrm{mg} / \mathrm{L})$} \\
\hline & $\begin{array}{c}\text { Not } \\
\text { treated }\end{array}$ & $\begin{array}{c}\text { Air } \\
\text { stripper }\end{array}$ & $\begin{array}{c}\text { Activated } \\
\text { carbon }\end{array}$ \\
\hline \multicolumn{4}{|c|}{ Volatiles (two samples each) } \\
\hline Acetone & $<0.010$ & $<0.010$ & $<0.010$ \\
\hline Toluene & 0.011 & 0.006 & $<0.005$ \\
\hline Xylene & 0.034 & 0.020 & $<0.005$ \\
\hline \multicolumn{4}{|c|}{ Semivolatiles (one sample each) } \\
\hline Naphthalene & 1.4 & 1.1 & $<0.01$ \\
\hline 4-Methylphenol & 0.42 & 0.43 & $<0.01$ \\
\hline 2,4-Dimethylphenol & 0.06 & 0.06 & $<0.01$ \\
\hline
\end{tabular}

\subsection{TRENCH T-16}

The water from trench T-16 lost only a small amount of volatile organics during handling prior to pumping the water into the air stripper (compare Tables 4 and 7). As with T-13 trench water, the T-16 trench water changed from brownish-green to brownish-orange after air stripping and was crystal clear after carbon adsorption. The water temperature decreased from 22 to $21^{\circ} \mathrm{C}$ in the air stripper, and the air temperature held at $23^{\circ} \mathrm{C}$. The pressure drop across the air stripper was $12 \mathrm{~Pa}\left(0.05\right.$ in $\left.\mathrm{H}_{2} \mathrm{O}\right)$, and there was not any visible foaming. The concentration of organics for the treated and untreated water is shown in Table 7, and additional results for the activated carbon treated water is shown in Table 9. 
Table 7. Treatment results for $\mathrm{T}-16$ trench water

\begin{tabular}{llll}
\hline & \multicolumn{3}{c}{ Contaminant concentration $(\mathrm{mg} / \mathrm{L})$} \\
\cline { 2 - 4 } \multicolumn{1}{c}{ Contaminant } & $\begin{array}{l}\text { Not } \\
\text { treated }\end{array}$ & $\begin{array}{l}\text { Air } \\
\text { stripper }\end{array}$ & $\begin{array}{l}\text { Activated } \\
\text { carbon }\end{array}$ \\
\hline $\begin{array}{l}\text { Volatiles (two samples each) } \\
\text { Toluene }\end{array}$ & & & \\
Xylene & 41 & 17 & $<0.005$ \\
Semivolatiles (one sample each) & 52 & 28 & $<0.005$ \\
Naphthalene & & & \\
4-Methylphenol & 13 & 6.1 & $<0.01$ \\
$\begin{array}{l}\text { Phenol } \\
\text { 2,4-Dimethylphenol }\end{array}$ & 1.5 & 1.3 & $<0.01$ \\
& 0.59 & 0.51 & $<0.01$ \\
\hline
\end{tabular}

\subsection{TRENCH T-105}

The water from trench T-105 lost only a small amount of volatile organics during handling prior to pumping the water into the air stripper (compare Tables 4 and 8 ). The water changed from brownish-green to brownish-orange to clear during treatment, as did the water from the other trenches. The water temperature decreased from 20 to $19^{\circ} \mathrm{C}$ in the air stripper, and the air temperature increased from 19 to $20^{\circ} \mathrm{C}$. The pressure drop across the air stripper was $12 \mathrm{~Pa}\left(0.05\right.$ in. $\left.\mathrm{H}_{2} \mathrm{O}\right)$, and there was not any visible foaming. The concentration of organics for the treated and untreated water is shown in Table 8 , and additional results for the activated carbon treated water is shown in Table 9.

Table 8. Treatment results for T-105 trench water

\begin{tabular}{llll}
\hline & \multicolumn{3}{c}{ Contaminant concentration $(\mathrm{mg} / \mathrm{L})$} \\
\cline { 2 - 4 } \multicolumn{1}{c}{ Contaminant } & $\begin{array}{l}\text { Not } \\
\text { treated }\end{array}$ & $\begin{array}{l}\text { Air } \\
\text { stripper }\end{array}$ & $\begin{array}{l}\text { Activated } \\
\text { carbon }\end{array}$ \\
\hline $\begin{array}{l}\text { Volatiles (two samples each) } \\
\text { Toluene }\end{array}$ & 34 & 13 & $<0.005$ \\
Xylene & 12 & 5.0 & $<0.005$ \\
Semivolatiles (one sample each) & & & $<0.01$ \\
Naphthalene & 3.1 & 2.0 & $<0.01$ \\
4-Methylphenol & 4.1 & 4.0 & $<0.01$ \\
2,4-Dimethylphenol & 0.45 & 0.40 & $<0.01$ \\
Phenol & 0.30 & 0.18 & \\
\hline
\end{tabular}


Table 9 shows the concentrations of selected contaminants in the trench water samples that were fully treated (i.e., softened and ion exchange treated for $\mathrm{T}-41$, and air stripper and activated carbon treated for T-13, T-16 and T-105). All of the contaminants shown have established effluent discharge limits set for either the PWTP or the NRWTP, and the treated trench water is substantially below these limits. Complete analytical results for metals and organics in the treated trench water samples are given in Appendix D.

Table 9. Contaminant concentrations in treated trench water

\begin{tabular}{|c|c|c|c|c|c|}
\hline \multirow[b]{2}{*}{ Contaminant } & \multicolumn{4}{|c|}{ Trench water sample location } & \multirow{2}{*}{$\begin{array}{c}\text { Discharge } \\
\text { limit }\end{array}$} \\
\hline & $\mathrm{T}-13$ & $\mathrm{~T}-41$ & $T-16$ & $\mathrm{~T}-105$ & \\
\hline \multicolumn{6}{|c|}{ Radionuclides (Bq/L) } \\
\hline${ }^{3} \mathrm{H}$ & 1900 & 180 & 180 & 1300 & 74,000 \\
\hline${ }^{60} \mathrm{Co}$ & $<0.1$ & 0.3 & 0.3 & 0.6 & 185 \\
\hline${ }^{90} \mathrm{Sr}$ & $<0.1$ & 0.5 & 0.5 & 0.6 & 37 \\
\hline${ }^{137} \mathrm{Cs}$ & $<0.1$ & 0.1 & $<0.1$ & 0.5 & 111 \\
\hline \multicolumn{6}{|l|}{ Metals (mg/L) } \\
\hline Cd & $<0.007$ & $<0.005$ & $<0.005$ & $<0.005$ & 1.20 \\
\hline $\mathrm{Cr}$ & $<0.004$ & 0.006 & 0.006 & 0.009 & 2.77 \\
\hline $\mathrm{Cu}$ & 0.28 & $<0.005$ & $<0.005$ & $<0.005$ & 3.38 \\
\hline $\mathrm{Pb}$ & $<0.03$ & $<0.05$ & $<0.05$ & $<0.05$ & 0.69 \\
\hline $\mathrm{Zn}$ & 0.11 & $<0.005$ & $<0.005$ & $<0.005$ & 2.61 \\
\hline $\begin{array}{l}\text { Total toxic } \\
\text { organics }(\mathrm{mg} / \mathrm{L})\end{array}$ & $<0.01$ & $<0.01$ & $<0.01$ & $<0.01$ & 2.13 \\
\hline
\end{tabular}

\section{DISCUSSION}

The high removal efficiency of the softening and ion-exchange treatment for ${ }^{90} \mathrm{Sr}$ in $\mathrm{T}-41$ trench water shows that there were not any complexing agents or other interferences in the water. The sampling that has been done to date at SWSA 6 indicates that water from very few of the trenches will need to be treated for radionuclides.

Using deionized water spiked with $40 \mathrm{mg} / \mathrm{L}$ xylene, the lab-scale air stripper removed $68 \%$ of the xylene in one pass. The removal efficiency for toluene and xylene in the trench water samples varied from 41 to $62 \%$, with an average of $52 \%$. The reduction in organic removal efficiency for the trench water compared to deionized water indicates that the trench 
water contains something that interferes slightly with air stripping, probably the suspended solids, (60 to $91 \%$ reduction in stripping efficiency compared to pure water).

To date, the concentration of volatile organics entering the air stripper at the NRWTP has been too low to allow experimental determination of the air stripper performance. The rigorous multistage separation model (RADFRC) in ASPEN (JSD Simulation Service Company, Denver, Colorado) was used to simulate the air stripper. At the maximum water flow rate for the NRWTP of $1300 \mathrm{~L} / \mathrm{min}$, and at water and air temperatures of $21^{\circ} \mathrm{C}$, ASPEN predicts that the NRWTP air stripper would remove $90 \%$ of the xylene or toluene present in the water at each theoretical stage. Since the NRWTP air stripper has nine theoretical stages at these conditions, a feed stream containing $100 \mathrm{mg} / \mathrm{L}$ xylene would contain $10^{-7} \mathrm{mg} / \mathrm{L}$ at the exit of the air stripper. At wintertime conditions of $10^{\circ} \mathrm{C}$ water temperature and $-7^{\circ} \mathrm{C}$ air temperature, ASPEN predicts that each stage would remove $80 \%$, so the same feed stream would contain $10^{-4} \mathrm{mg} / \mathrm{L}$ xylene after air stripping during cold weather.

If the removal efficiency of each theoretical stage is reduced by $60 \%$ because of interfering contaminants in the trench water (the worst case seen in the treatability tests) the effluent from the NRWTP air stripper would contain $0.3 \mathrm{mg} / \mathrm{L}$ xylene for an inlet stream of $100 \mathrm{mg} / \mathrm{L}$ at winter conditions. This effluent would be below the NPDES limit of $2.13 \mathrm{mg} / \mathrm{L}$ for total toxic organics at the NRWTP, even before the astivated carbon treatment, which would further reduce the organic concentration. The above calculations show that the NRWTP air stripper is easily able to treat the trench water from WAG 6, even at extreme conditions.

The lab-scale activated carbon column was able to produce water containing undetectable concentrations of organics even though the feed to this column contained much higher concentrations of organics than the feed to the NRWTP carbon columns. The NRWTP columns would be expected to produce lower concentrations for the same wastewater, because of the higher number of stages in its air stripper.

The results of the treatability tests demonstrate that the trench water from WAG 6 can be treated at the PWTP for ${ }^{90} \mathrm{Sr}$, and at the NRWTP for organics.

\section{CONCLUSIONS}

Lab-scale treatability tests on trench water from SWSA 6 have shown that the water can be successfully treated by existing wastewater treatment plants at ORNL. Water from the four most highly contaminated trenches identified to date was used in the treatability tests. The softening and ion-exchange processes used in the Process Wastewater Treatment Plant reduced the ${ }^{90} \mathrm{Sr}$ concentration, which was the only radionuclide present in the trench water at above the discharge limits, from 260 to $0.2 \mathrm{~Bq} / \mathrm{L}$. The air stripping and activated carbon adsorption processes used in the NRWTP removed volatile and semivolatile organics, which were the main contaminants in the trench water, to below detection limits. The trench water treated in the lab-scale equipment easily met all discharge requirements for effluent from the PWTP and the NRWTP. 


\section{REFERENCES}

1. U.S. Department of Energy, Order 5400.5, "Radiation Protection of the Public and the Environment," February 8, 1990.

2. D. K. Solomon et. al., Sampling and Analysis of SWSA 6 Trench Leachates and Groundwaters, ORNL/TM-10813, Martin Marietta Energy Systems, Inc., Oak Ridge National Lab., December 1988.

3. B. P. Spalding, Environmental Sciences Division, ORNL, unpublished data, 1989.

4. B. P. Spalding, "Task Plan For Evaluation of Stabilization of Inundated Waste Burial Trenches by Dynamic Compaction at Test Area For Remedial Actions-Site II at ORNL Solid Waste Storage Area 6," September 29, 1989, Attachment to Letter from K. W. Cook (ORNL) to T. Wheeler (DOE), dated November 20, 1989.

5. J. H. Perry ed., Chemical Engineers' Handbook, 4th ed., McGraw-Hill Book Company, New York, 1969.

6. Z. R. Jovanovic, M. Todorovic, and I. J. Gal, "The Fxchange of Tritiated Water Between Zn-A Zeolite and the Surrounding Water," Croat Chem Acta 60 (4), 655-660, 1987. 
Appendix A

\section{RESULTS OF ANALYSES OF TRENCH WATER \\ SAMPLES FROM SWSA 6, 1986-87}

'D. K. Solomon et al., Sampling and Analysis of SWSA 6 Trench Leachates and Groundwaters, ORNL/TM-10813, Martin Marietta Energy Systems, Inc., Oak Ridge National Lab., December 1988. 
Table Al. Inductively-coupled plasma spectrometric analyses of trench water (in $\mathrm{mg} / 1$ )

Well IO/sampling date

\begin{tabular}{|c|c|c|c|c|c|c|c|c|}
\hline Element & $\begin{array}{c}141 \\
3 / 11 / 86\end{array}$ & $\begin{array}{c}141 \\
12 / 4 / 86\end{array}$ & $\begin{array}{c}141 \\
3 / 10 / 87\end{array}$ & $\begin{array}{c}192 \\
4 / 22 / 86\end{array}$ & $\begin{array}{c}192 \\
12 / 4 / 86\end{array}$ & $\begin{array}{c}192 \\
3 / 10 / 87\end{array}$ & $\begin{array}{c}1 / 35 \\
4 / 13 / 87\end{array}$ & $\begin{array}{c}T 163 \\
4 / 21 / 87\end{array}$ \\
\hline Ag & $<0.050$ & $<0.050$ & $<0.005$ & $<0.050$ & $<0.050$ & $<0.005$ & $<0.005$ & $\infty .005$ \\
\hline Al & $<0.200$ & $<0.200$ & $<0.020$ & $<0.200$ & $<0.200$ & $<0.020$ & 0.02 & 0.035 \\
\hline As & $<0.330$ & $<0.10$ & $\leqslant 0.010$ & $<0.005$ & $\infty 0.10$ & $<0.010$ & $<0.010$ & $\infty .010$ \\
\hline B & 0.35 & 0.48 & 0.17 & 0.08 & $\infty .08$ & 0.084 & 0.25 & 0.094 \\
\hline $\mathbf{B a}$ & 0.18 & 0.14 & 0.2 & 0.14 & 0.21 & 0.089 & 0.16 & 0.061 \\
\hline Be & $<0.002$ & $\infty .002$ & $\infty 0.0002$ & $<0.002$ & $\infty .002$ & $\infty .0002$ & $<0.0002$ & $\$ 0.0002$ \\
\hline $\mathrm{Ca}$ & 140 & 120 & 110 & 37 & 48 & 34 & 89 & 31 \\
\hline $\operatorname{co}$ & 0.005 & $\infty .005$ & 0.0019 & $<0.005$ & $\infty .005$ & $\infty .0005$ & 0.004 & 0.0016 \\
\hline co & 0.01 & 0.015 & 0.0068 & $\infty 0.022$ & $\infty .010$ & 0.013 & 0.008 & 0.0068 \\
\hline $\mathrm{Cr}$ & $<0.040$ & $\infty .040$ & $\infty 0.0053$ & $<0.040$ & $\infty .040$ & $\infty .0040$ & $<0.0040$ & $\infty 0.0040$ \\
\hline$a_{1}$ & $<0.020$ & $\infty 0.020$ & $<0.002$ & $<0.020$ & $\infty .020$ & $\infty .002$ & 0.002 & 0.0025 \\
\hline $\mathrm{Fe}$ & 23 & 37 & 34 & 1.1 & 23 & 6.2 & 50 & $<1.000$ \\
\hline Ga & $<0.300$ & $<0.300$ & $<0.030$ & $\infty 0.300$ & $\infty .300$ & $\infty 0.030$ & $<0.030$ & $\infty .030$ \\
\hline li & $<0.200$ & $<0.200$ & $<0.020$ & $<0.200$ & $\infty .200$ & $<0.020$ & $<0.1900$ & $\infty .020$ \\
\hline $\mathrm{Mg}$ & 25 & 26 & 24 & 9.1 & 9.6 & 6.8 & 17 & 8.1 \\
\hline$M n$ & 5 & 5.2 & 4.5 & 9.4 & 8 & 6.6 & 3.5 & 1.5 \\
\hline Ho & $<0.040$ & $<0.040$ & 0.028 & $<0.040$ & $\infty .040$ & $<0.004$ & $<0.0040$ & $\infty .004$ \\
\hline $\mathrm{Na}$ & 42 & 28 & 27 & 1.1 & 23 & 9.8 & 7.1 & 1.8 \\
\hline $\mathrm{Ni}$ & 0.08 & 0.21 & 0.034 & 0.06 & $\dot{\infty} 0.06$ & $<0.006$ & $\infty .0120$ & $\infty .006$ \\
\hline$P$ & 0.41 & 0.54 & 0.46 & $<0.300$ & 2 & 0.2 & 1.8 & 0.79 \\
\hline Pb & $<0.200$ & $\infty .200$ & $\infty .020$ & $<0.010$ & $\infty .20$ & $\infty .020$ & $<0.020$ & $\infty .020$ \\
\hline Sb & $<0.020$ & $<0.20$ & $<0.020$ & $<0.200$ & $<0.200$ & $<0.020$ & $<0.020$ & $<0.020$ \\
\hline Se & $<0.020$ & $<0.20$ & $<0.020$ & $<0.010$ & $<0.20$ & $\infty .020$ & $<0.020$ & $<0.020$ \\
\hline Si & 3.9 & 3.6 & 3.3 & 4.7 & 6.2 & 3.8 & 1.9 & 1.1 \\
\hline Sn & $<0.050$ & $<0.050$ & $<0.005$ & $<0.050$ & $<0.050$ & $<0.005$ & $<0.0050$ & $<0.0050$ \\
\hline$S r$ & 0.14 & 0.23 & 0.2 & 0.11 & 0.13 & 0.014 & 0.15 & 0.042 \\
\hline $\mathrm{Ti}$ & $<0.020$ & $<0.020$ & $<0.002$ & $<0.020$ & $\infty .020$ & $\infty 0.002$ & 0.002 & 0.0057 \\
\hline $\mathbf{v}$ & $<0.010$ & $<0.0010$ & 0.001 & $<0.010$ & $\infty .0010$ & $<0.001$ & 0.001 & 0.001 \\
\hline $2 n$ & 0.041 & 0.083 & 0.0073 & $<0.020$ & $<0.020$ & 0.023 & $<0.0560$ & $<0.0330$ \\
\hline $2 r$ & $<0.020$ & $<0.020$ & $<0.002$ & $<0.020$ & $<0.020$ & $<0.002$ & $<0.0020$ & $<0.002$ \\
\hline
\end{tabular}


Table A1 (continued)

Will I0/sampling date

\begin{tabular}{ccccccccc} 
& & & & & & & \\
Element & 1219 & 1257 & 1257 & 1257 & $1260-2$ & 1288 & 1288 & 1288 \\
& $1 / 21 / 87$ & $12 / 5 / 86$ & $1 / 21 / 87$ & $3 / 10 / 87$ & $4 / 13 / 87$ & $3 / 21 / 86$ & $12 / 5 / 86$ & $3 / 10 / 87$ \\
\hline
\end{tabular}

\begin{tabular}{|c|c|c|c|c|c|c|c|c|}
\hline $\begin{array}{l}\text { Ag } \\
\text { AI }\end{array}$ & $\begin{array}{l}\infty .03 \\
\infty .120\end{array}$ & $\begin{array}{l}\infty .050 \\
\infty 0.200\end{array}$ & $\begin{array}{c}\infty .005 \\
0.03\end{array}$ & $\begin{array}{l}\infty .005 \\
\infty .020\end{array}$ & $\begin{array}{l}\infty .005 \\
0.02\end{array}$ & $\begin{array}{l}\infty 0.050 \\
<0.200\end{array}$ & $\begin{array}{l}\infty .050 \\
\infty .200\end{array}$ & $\begin{array}{l}\$ .005 \\
\$ 0.020\end{array}$ \\
\hline As & $\infty 0.060$ & $\infty .10$ & $\infty .010$ & $\infty .010$ & $\infty .010$ & $<0.005$ & $<0.10$ & $\infty .010$ \\
\hline$B$ & $\infty .048$ & $\infty .08$ & 0.022 & $\infty 0.008$ & 0.008 & 0.08 & $\infty . \infty 8$ & $<0.008$ \\
\hline Ba & 0.1 & $\infty .099$ & 0.12 & 0.068 & 0.13 & 0.2 & 0.28 & 0.18 \\
\hline Be & $\infty .0012$ & $\infty .002$ & $\infty .0002$ & $\infty 0.0002$ & $\infty .0002$ & $\infty 0.002$ & $\infty .002$ & $\infty .0002$ \\
\hline Ca & 150 & 31 & 36 & 32 & 38 & 47 & 12 & 52 \\
\hline cd & $\infty . \infty$ & $\infty .005$ & 0.0012 & $\infty .0005$ & 0.0033 & $\infty .005$ & $\infty .005$ & 0.0021 \\
\hline$\infty$ & 0.014 & $\infty .010$ & 0.047 & $\infty .001$ & 0.019 & $\infty .010$ & $\infty .016$ & 0.0099 \\
\hline cr & $\infty .024$ & $\infty .040$ & 0.0049 & $\infty .004$ & $\$ 0.0040$ & $\infty .040$ & $\infty 0.040$ & $\infty .004$ \\
\hline ou & $\infty .012$ & $\infty .020$ & $\infty .002$ & $\infty .002$ & 0.002 & $\infty .020$ & $\infty .020$ & $\infty .002$ \\
\hline Fe & 24 & 0.33 & 17 & 0.0087 & $\$ 0$ & 50 & 69 & 45 \\
\hline a & $\infty .180$ & $\infty .300$ & $\infty .030$ & $\infty .030$ & $\varnothing 0.030$ & $\$ 0.300$ & $\$ 0.300$ & $\infty .030$ \\
\hline Li & $\infty .120$ & $\infty 0.200$ & $\infty .020$ & $\infty .020$ & $<0.0200$ & $\infty .200$ & $\infty 0.200$ & $\infty 0.020$ \\
\hline mg & 22 & 4.6 & 11 & 3.7 & 13 & 13 & 18 & 12 \\
\hline$m$ & 5.7 & 0.35 & 7 & 0.00081 & 4.3 & 5.8 & 8.5 & 5.4 \\
\hline no & $<0.024$ & $\infty 0.040$ & 0.011 & $<0.004$ & $\infty .0040$ & $<0.040$ & $<0.040$ & 0.014 \\
\hline $\mathrm{Ma}$ & 2.9 & 13 & 18 & 8.5 & 130 & 2.6 & 3.1 & 1.4 \\
\hline $\mathrm{Mi}$ & $<0.036$ & $\infty .06$ & 0.014 & $\infty .006$ & $<0.0060$ & 0.06 & $\infty 0.06$ & 0.006 \\
\hline $\mathbf{P}$ & $<.180$ & 0.62 & 0.12 & 0.13 & 0.1 & 0.63 & 0.84 & 0.64 \\
\hline Po & $<0.120$ & $\infty 0.20$ & $<0.020$ & $<0.020$ & $\infty 0.020$ & $<0.010$ & $<0.20$ & $<0.020$ \\
\hline sb & $<0.120$ & $<0.20$ & $\infty 0.020$ & $<0.020$ & $<0.020$ & $<0.020$ & $<0.20$ & $<0.020$ \\
\hline se & $<0.120$ & $\infty .20$ & $<0.020$ & $\infty .020$ & $<0.020$ & $\infty 0.010$ & $\infty .20$ & $<0.020$ \\
\hline si & 0.53 & 2 & 0.14 & 2.1 & 1.3 & 4.3 & 5.4 & 3.3 \\
\hline Sn & $<0.030$ & $<0.050$ & $<0.005$ & $\infty .005$ & $<0.0050$ & $<0.050$ & $<0.050$ & $<0.005$ \\
\hline $\mathrm{sr}$ & 0.17 & 0.061 & 0.072 & 0.05 & 0.075 & 0.092 & 0.13 & 0.078 \\
\hline $\boldsymbol{r i}$ & $<0.012$ & $\infty .020$ & 0.0048 & $\infty .002$ & 0.0038 & $<0.020$ & $\varnothing 0.020$ & $<0.002$ \\
\hline $\mathbf{v}$ & 0.0097 & $\infty .001$ & $\infty 0.0010$ & 0.0018 & 0.001 & $\infty .010$ & $\infty .001$ & $\infty .001$ \\
\hline $2 n$ & $\infty .012$ & $\infty 0.020$ & 0.44 & 0.006 & $\$ .0190$ & $<0.020$ & $\infty .020$ & 0.0069 \\
\hline $2 r$ & $<0.012$ & $\infty 0.020$ & $\infty .002$ & $\infty .002$ & $\infty .0020$ & $<0.020$ & $\infty .020$ & $\infty .002$ \\
\hline
\end{tabular}


Table A2. Chemical, ion chromatographic, and atomic adsorption analyses of trench water ( $1 \mathrm{n} \mathrm{mg} / \mathrm{L}$ )

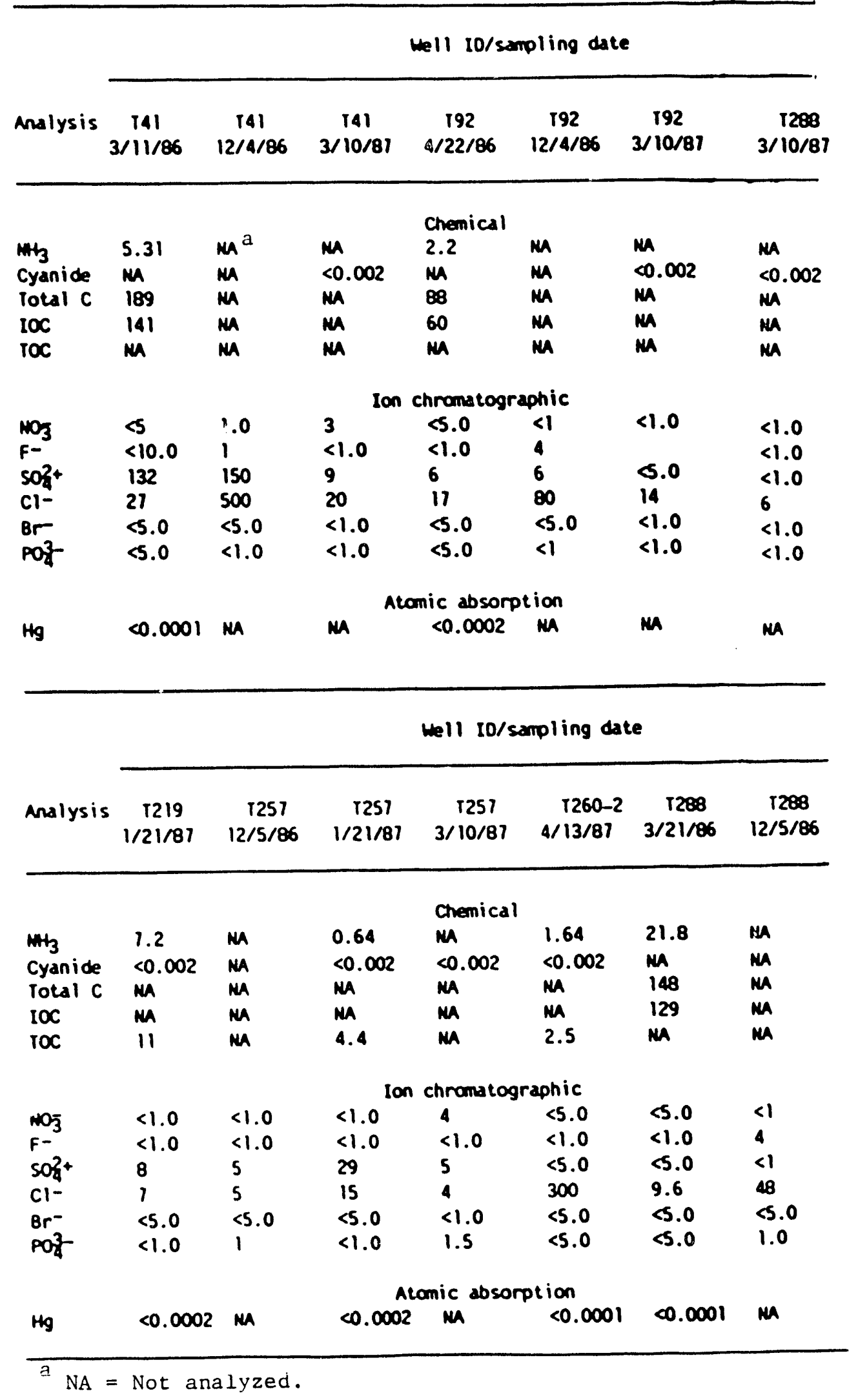


Table A3. Radiochemical analyses of trench water (1n Bq/L)

Hell to/sampling date

\begin{tabular}{lllllll} 
Analysis & \multicolumn{1}{c}{$\begin{array}{c}\text { TA1 } \\
3 / 11 / 86\end{array}$} & \multicolumn{1}{c}{$\begin{array}{c}141 \\
12 / 4 / 86\end{array}$} & $\begin{array}{c}141 \\
3 / 10 / 81\end{array}$ & $\begin{array}{c}192 \\
1 / 22 / 86\end{array}$ & $\begin{array}{c}192 \\
12 / 4 / 85\end{array}$ & $\begin{array}{c}192 \\
3 / 10 / 87\end{array}$ \\
\hline Gross alpha & $8.6 \pm 5.3$ & $110 \pm 45$ & $1.1 \pm 1.8$ & $1.5 \pm 1.7$ & $0.7 \pm 1.4$ & $1 \pm 1$ \\
Gross beta & $5400 \pm 100$ & $18.000 \pm 1000$ & $16.000 \pm 1000$ & $150 \pm 10$ & $16 \pm 4$ & $9.4 \pm 3.4$
\end{tabular}

\begin{tabular}{|c|c|c|c|c|c|c|}
\hline $\begin{array}{l}3 \mathrm{H} \\
{ }^{14} \mathrm{C} \\
{ }^{60} \mathrm{Co} \\
{ }^{90} \\
{ }_{\mathrm{Sr}} \\
{ }^{99} \mathrm{IC}\end{array}$ & $\begin{array}{l}2000 \pm 100 \\
1.9 \\
M \\
3600 \pm 100 \\
<100\end{array}$ & $\begin{array}{l}340,000 \pm 10,000 \\
m^{a} \\
<0.6 \\
3100 \pm 100 \\
<100\end{array}$ & $\begin{array}{l}180,000 \pm 10,000 \\
2900 \pm 100 \\
<0.6 \\
\mathrm{~mA} \\
<100\end{array}$ & $\begin{array}{l}2200 \pm 100 \\
42 \pm 18 \\
0.22 \pm 0.08 \\
86 \pm 12 \\
<100\end{array}$ & $\begin{array}{l}2600 \pm 100 \\
m \\
<0.3 \\
0.84 \pm 0.20 \\
<100\end{array}$ & $\begin{array}{l}1500 \pm 100 \\
81 \\
\infty .1 \\
\mathrm{mel} \\
<100\end{array}$ \\
\hline $\begin{array}{l}{ }^{131} \mathrm{cs} \\
228 \mathrm{in} \\
230 \mathrm{in} \\
234 \mathrm{u} \\
{ }^{235} \mathrm{u}\end{array}$ & $\begin{array}{l}88 \pm 6 \\
0.17 \pm 0.2 \\
0.03 \pm 0.01 \\
0.63 \pm 0.01 \\
0.11 \pm 0.03\end{array}$ & $\begin{array}{l}130 \pm 10 \\
\text { MLC } \\
\text { MNL } \\
\text { MAL } \\
\text { MAL }\end{array}$ & $\begin{array}{l}140 \pm 10 \\
\text { MAL } \\
\text { MAL } \\
\text { MAL } \\
\text { NAL }\end{array}$ & $\begin{array}{l}2.6 \pm 0.2 \\
\mathrm{mLC} \\
\mathrm{mal} \\
\mathrm{mLC} \\
\mathrm{mLC}\end{array}$ & $\begin{array}{l}0.33+0.28 \\
\mathrm{mal} \\
\mathrm{mal} \\
\mathrm{mLC} \\
\mathrm{mal}\end{array}$ & $\begin{array}{l}0.59 \pm 0.13 \\
\mathrm{mLC} \\
\mathrm{MLC} \\
\mathrm{MLC} \\
\mathrm{MAL}\end{array}$ \\
\hline $\begin{array}{l}238 \mathrm{U} \\
\text { Total Ra }\end{array}$ & $\begin{array}{l}0.36 \pm 0.05 \\
0.47 \pm 0.18\end{array}$ & MAL & $\begin{array}{l}\text { MAL } \\
\text { MAL }\end{array}$ & $\begin{array}{l}\mathrm{mal} \\
<0.02\end{array}$ & mal & $\begin{array}{l}\text { MAL } \\
\text { MAL }\end{array}$ \\
\hline
\end{tabular}
a NA $=$ Not analyzed.
b NAL $=$ Not analyzed. 
Table A3 (continued)

\begin{tabular}{|c|c|c|c|c|c|c|}
\hline \multirow[b]{2}{*}{ Amlysis } & \multicolumn{6}{|c|}{ Hell 10/sampling date } \\
\hline & $\begin{array}{c}T 135 \\
4 / 13 / 61\end{array}$ & $\begin{array}{c}T / 63 \\
4 / 21 / 87\end{array}$ & $\begin{array}{c}1219 \\
1 / 21 / 87\end{array}$ & $\begin{array}{c}125] \\
12 / 5 / 86\end{array}$ & $\begin{array}{c}1251 \\
\mid / 21 / 81\end{array}$ & $\begin{array}{c}1251 \\
3 / 10 / 81\end{array}$ \\
\hline Gross alpha & $0.6 \pm 1$ & $1 \pm 1.7$ & $<2.0$ & $2.9 \pm 2.4$ & $4.2 \pm 3$ & $2 \pm 2.1$ \\
\hline Gross beta & $5400 \pm 100$ & $26 \cdot \pm 5$ & $20 \pm 5$ & $9.4 \pm 3.1$ & $1100 \pm 100$ & $1 \pm 2.4$ \\
\hline $\begin{array}{l}{ }_{\mathrm{H}}^{3} \\
{ }^{14} \mathrm{C} \\
{ }_{60} \mathrm{Co} \\
{ }_{90} \mathrm{Sr} \\
{ }^{99} \mathrm{IC}\end{array}$ & $\begin{array}{l}33,000 \pm 1000 \\
2600 \pm 100 \\
0.1 \pm 0.22 \\
<A \\
<100\end{array}$ & $\begin{array}{l}620 \pm 50 \\
32 \pm 21 \\
0.33 \pm 0.18 \\
\mathrm{MAL} \\
<100\end{array}$ & $\begin{array}{l}300 \pm 40 \\
30 \pm 20 \\
<2 \\
\mathrm{MAL} \\
<100\end{array}$ & $\begin{array}{l}23.000 \pm 1000 \\
M \\
\infty .3 \\
0.26 \pm 0.13 \\
<100\end{array}$ & $\begin{array}{l}3900 \pm 100 \\
410 \pm 30 \\
1.4 \pm 0.4 \\
M A \\
<100\end{array}$ & $\begin{array}{l}12,000 \pm 1000 \\
1 \pm 20 \\
<0.2 \\
\mathrm{kAC} \\
<100\end{array}$ \\
\hline${ }^{238}{ }^{230} \mathrm{Th}$ & $\begin{array}{l}40 \pm 1 \\
\text { MAL } \\
\text { MAL } \\
\text { MAL } \\
\text { MAL }\end{array}$ & $\begin{array}{l}2.4 \pm 0.2 \\
\mathrm{MAL} \\
\mathrm{MAL} \\
\mathrm{KAL} \\
\mathrm{MAL}\end{array}$ & $\begin{array}{l}3 \pm 0.4 \\
\text { MAL } \\
\text { NAL } \\
\text { MAL } \\
\text { MAL }\end{array}$ & $\begin{array}{l}\angle 0.3 \\
\mathrm{MAL} \\
\mathrm{MAL} \\
\mathrm{MAL} \\
\mathrm{MLC}\end{array}$ & $\begin{array}{l}2.1 \pm 0.4 \\
\text { MAL } \\
\text { MAL } \\
\text { MAL } \\
\text { MAL }\end{array}$ & $\begin{array}{l}<0.2 \\
\mathrm{MAL} \\
\mathrm{MAL} \\
\mathrm{MAL} \\
\mathrm{MAL}\end{array}$ \\
\hline${ }^{238} u$ & MAL & $M A L$ & MAL & MAL & MAL & MAL \\
\hline Tolal Ra & MAL & MAL & $0.11 \pm 0.05$ & MAL & $<0.1$ & MAL \\
\hline
\end{tabular}


Table A3 (continued)

\begin{tabular}{|c|c|c|c|c|}
\hline \multirow[b]{2}{*}{ Analysis } & & & \multicolumn{2}{|c|}{ Hell 10/sampling date } \\
\hline & $\begin{array}{r}1260-2 \\
4 / 13 / 81\end{array}$ & $\begin{array}{c}1288 \\
3 / 21 / 86\end{array}$ & $\begin{array}{c}1288 \\
12 / 5 / 86\end{array}$ & $\begin{array}{c}1288 \\
3 / 10 / 81\end{array}$ \\
\hline Gross alpha & $0.4 \pm 1$ & $1.9 \pm 2$ & $2.5 \pm 2.3$ & $1 \pm 2$ \\
\hline Gross beta & $3.9 \pm 3$ & $4.9 \pm 2.9$ & $52 \pm 7$ & $9.1 \pm 3.4$ \\
\hline H & $310 \pm 40$ & $400 \pm 90$ & $1200 \pm 100$ & $570 \pm 50$ \\
\hline c & $19 \pm 20$ & $10 \pm 35$ & $M$ & $10 \pm 20$ \\
\hline 0 & $<0.2$ & $0.88 \pm 0.26$ & $0.43 \pm 0.29$ & $\infty .2$ \\
\hline & MAL & MLL & $12 \pm 1$ & MAL \\
\hline IC & $<100$ & $<100$ & $<100$ & $<100$ \\
\hline${ }^{131} \mathrm{cs}$ & $<0.3$ & $<0.1$ & $1.2 \pm 0.3$ & $0.29 \div 0.11$ \\
\hline in & MAL & MAL & MAL & MAL \\
\hline $230 \mathrm{in}$ & MLL & MAL & MAL & male \\
\hline${ }^{234} u$ & MAL & MAL & MAL & MAL \\
\hline${ }^{235} \mathrm{u}$ & MAL & MAL & MAL & MAL \\
\hline${ }^{238} u$ & NAL & MAL & MAL & MAL \\
\hline Total Rd & MAL & $<0.02$ & MAL & MAL \\
\hline
\end{tabular}


Table A4. Gas chromatograph1c-mass spectrographlc analyses of trench water (In $\left.\mu g / L_{1}\right)$

Well I0/sampling date

Compound

\begin{tabular}{ccccccc}
\hline 192 & $T 135$ & $T 163$ & $T 219$ & $T 257$ & $T 260-2$ & $T 288$ \\
$4 / 22 / 86$ & $4 / 13 / 87$ & $4 / 21 / 87$ & $1 / 21 / 87$ & $1 / 21 / 87$ & $4 / 13 / 87$ & $4 / 29 / 86$
\end{tabular}

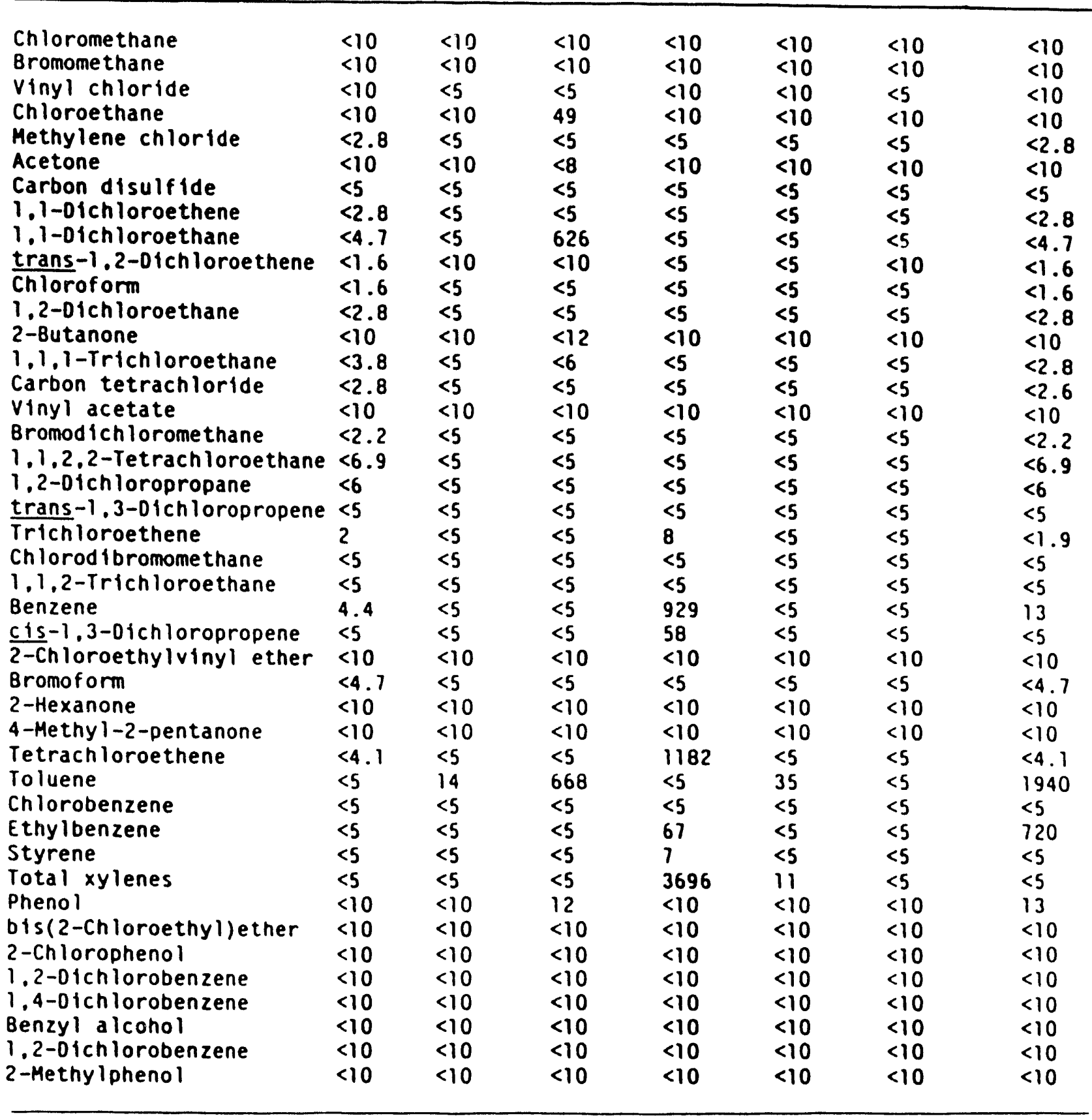


Table A4 (continued)

Well IO/sampling date

Compound

\begin{tabular}{ccccccc}
\hline 92 & $T 135$ & $T 163$ & $T 219$ & $T 257$ & $T 260-2$ & $T 288$ \\
$4 / 22 / 86$ & $4 / 13 / 87$ & $4 / 21 / 87$ & $1 / 21 / 87$ & $1 / 21 / 87$ & $4 / 13 / 87$ & $4 / 29 / 86$
\end{tabular}

\begin{tabular}{|c|c|c|c|c|c|c|c|}
\hline $\begin{array}{l}\text { bis(2-Chlorolsopropyl)ether } \\
\text { 4-Hethylphenol }\end{array}$ & $\begin{array}{l}<10 \\
<10\end{array}$ & $\begin{array}{l}<10 \\
<10\end{array}$ & $\begin{array}{l}<10 \\
91\end{array}$ & $\begin{array}{l}<10 \\
34\end{array}$ & $\begin{array}{l}<10 \\
<10\end{array}$ & $\begin{array}{l}<10 \\
<10\end{array}$ & $\begin{array}{l}<10 \\
<10\end{array}$ \\
\hline N-nitrosodipropylamine & $<20$ & $<10$ & $<20$ & $<20$ & $<20$ & $<10$ & $<20$ \\
\hline Hexachloroethane & $<10$ & $<10$ & $<10$ & $<10$ & $<10$ & $<10$ & $<10$ \\
\hline Nitrobenzene & $<10$ & $<10$ & $<10$ & $<10$ & $<10$ & $<10$ & $<10$ \\
\hline Isophorone & .10 & $<10$ & $<10$ & $<10$ & $<10$ & $<10$ & $<10$ \\
\hline 2-Nitrophenol & $<20$ & $<10$ & $<10$ & $<20$ & $<20$ & $<10$ & $<20$ \\
\hline 2,4-01methylphenol & $<10$ & $<10$ & $<10$ & $<10$ & $<10$ & $<10$ & 32 \\
\hline Benzolc acid & $<50$ & $<50$ & $<50$ & $<50$ & $<50$ & $<50$ & $<50$ \\
\hline bis (2-Chloroethoxy) methane & $<10$ & $<10$ & $<10$ & $<10$ & $<10$ & $<10$ & $<10$ \\
\hline 2.4-D1chlorophenol & $<10$ & $<10$ & $<10$ & $<10$ & $<10$ & $<10$ & $<10$ \\
\hline $1.2 .4-T r$ Ichlorobenzene & $<10$ & $<10$ & $<10$ & $<10$ & $<10$ & $<10$ & $<10$ \\
\hline Naphthalene & 51 & $<10$ & $<10$ & 354 & $<10$ & $<10$ & 1704 \\
\hline 4-Chloroantiline & $<10$ & $<10$ & $<10$ & $<10$ & $<10$ & $<10$ & $<10$ \\
\hline Hexachlorobutadiene & $<10$ & $<10$ & $<10$ & $<10$ & $<10$ & $<10$ & $<10$ \\
\hline 4-Chloro-3-methylphenol & $<10$ & $<10$ & $<10$ & $<10$ & $<10$ & $<10$ & $<10$ \\
\hline 2-Hethylnaphthalene & $<10$ & $<10$ & $<10$ & $<10$ & $<10$ & $<10$ & $<10$ \\
\hline Hexachlorocyclopentadiene & $<10$ & $<10$ & $<10$ & $<10$ & $<10$ & $<10$ & $<10$ \\
\hline 2.4.6-Trichlorophenol & $<10$ & $<10$ & $<10$ & $<10$ & $<10$ & $<10$ & $<10$ \\
\hline 2,4,5-Trichlorophenol & $<10$ & $<50$ & $<50$ & $<50$ & $<50$ & $<50$ & $<10$ \\
\hline 2-Chloronaphthalene & $<10$ & $<10$ & $<10$ & $<10$ & $<10$ & $<10$ & $<10$ \\
\hline Dimethyl phthalate & $<10$ & $<10$ & $<10$ & $<10$ & $<10$ & $<10$ & $<10$ \\
\hline Acenaphthylene & $<10$ & $<10$ & $<10$ & $<10$ & $<10$ & $<10$ & $<10$ \\
\hline Acenaphthene & $<10$ & $<10$ & $<10$ & $<10$ & $<10$ & $<10$ & $<10$ \\
\hline 2,4-Dinitrophenol & $<50$ & $<50$ & $<50$ & $<50$ & $<50$ & $<50$ & $<50$ \\
\hline 4-Nitrophenol & $<50$ & $<50$ & $<50$ & $<50$ & $<50$ & $<50$ & $<50$ \\
\hline Dibenzofuran & $<10$ & $<10$ & $<10$ & $<10$ & $<10$ & $<10$ & $<10$ \\
\hline 2.4-0initrotoluene & $<10$ & $<10$ & $<10$ & $<10$ & $<10$ & $<10$ & $<10$ \\
\hline Dinitrotoluene & $<10$ & $<10$ & $<10$ & $<10$ & $<10$ & $<10$ & $<10$ \\
\hline Diethylphthalate & $<10$ & $<10$ & $<10$ & $<10$ & $<10$ & $<10$ & $<10$ \\
\hline 4-Chlorophenyl-phenylether & $<10$ & $<10$ & $<10$ & $<10$ & $<10$ & $<10$ & $<10$ \\
\hline Fluorene & $<10$ & $<10$ & $<10$ & $<10$ & $<10$ & $<10$ & $<10$ \\
\hline 4,6-0inttro-2-methylphenol & $<20$ & $<50$ & $<50$ & $<50$ & $<50$ & $<50$ & $<20$ \\
\hline N-nitrosodiphenylamine (1) & $<20$ & $<10$ & $<10$ & $<10$ & $<10$ & $<10$ & $<20$ \\
\hline 4-Bromophenyl-phenylether & $<10$ & $<10$ & $<10$ & $<10$ & $<10$ & $<10$ & $<10$ \\
\hline Hexachlorobenzene & $<10$ & $<10$ & $<10$ & $<10$ & $<10$ & $<10$ & $<10$ \\
\hline Pentachlorophenol & $<50$ & $<50$ & $<50$ & $<50$ & $<50$ & $<50$ & $<50$ \\
\hline Phenanthrene & $<10$ & $<10$ & $<10$ & $<10$ & $<10$ & $<10$ & $<10$ \\
\hline Anthracene & $<10$ & $<10$ & $<10$ & $<10$ & $<10$ & $<10$ & $<10$ \\
\hline 01-N-butylphthalate & $<10$ & $<10$ & $<10$ & $<10$ & $<10$ & $<10$ & $<10$ \\
\hline Fluoranthene & $<10$ & $<10$ & $<10$ & $<10$ & $<10$ & $<10$ & 10 \\
\hline Pyrene & $<10$ & $<10$ & $<10$ & $<10$ & $<10$ & $<10$ & $<10$ \\
\hline Butylbenzylphthalate & $<10$ & $<10$ & $<10$ & $<10$ & $<10$ & $<10$ & $<10$ \\
\hline
\end{tabular}


Table A4 (continued)

We 11 I0/sampling date

Compound

$T 92$

1135

1163

T219

T257

1260-2

T288

$4 / 22 / 86$

$4 / 13 / 87 \quad 4 / 21 / 87 \quad 1 / 21 / 87 \quad 1 / 21 / 87 \quad 4 / 13 / 87 \quad 4 / 29 / 86$

\begin{tabular}{|c|c|c|c|c|c|c|c|}
\hline 3,3-Dichlorobenzidine & $<50$ & $<20$ & $<20$ & $<20$ & $<50$ & $<20$ & $<50$ \\
\hline Benz(a) anthracene & $<10$ & $<10$ & $<10$ & $<10$ & $<10$ & $<10$ & $<10$ \\
\hline bis(2-Ethylhexyl)phthalate & $<10$ & $<10$ & $<10$ & $<10$ & $<10$ & $<10$ & $<10$ \\
\hline Chrysene & $<10$ & $<10$ & $<10$ & $<10$ & $<10$ & $<10$ & $<10$ \\
\hline 01-N-octyl phthalate & $<10$ & $<10$ & $<10$ & $<10$ & $<10$ & $<10$ & $<10$ \\
\hline Benzo (b) fluoranthene & $<10$ & $<10$ & $<10$ & $<10$ & $<10$ & $<10$ & $<10$ \\
\hline Benzo(k)fluoranthene & $<10$ & $<10$ & $<10$ & $<10$ & $<10$ & $<10$ & $<10$ \\
\hline Benzo(a) pyrene & $<10$ & $<10$ & $<10$ & $<10$ & $<10$ & $<10$ & $<10$ \\
\hline Indeno $(1,2,3-\mathrm{CO})$ pyrene & $<10$ & $<10$ & $<10$ & $<10$ & $<10$ & $<10$ & $<10$ \\
\hline Dlbenz $(a, h)$ anthracene & $<20$ & $<10$ & $<10$ & $<10$ & $<20$ & $<10$ & $<20$ \\
\hline Benzo( $g, h, 1$ perylene & $<20$ & $<10$ & $<10$ & $<10$ & $<20$ & $<10$ & $<20$ \\
\hline e-Chioro-m-cresol & $<10$ & $<10$ & $<10$ & $<10$ & $<10$ & $<10$ & $<10$ \\
\hline o-Cresol & $<10$ & $<10$ & $<10$ & $<10$ & $<10$ & $<10$ & 26 \\
\hline $\bar{p}-$ Cresol & $<10$ & $<10$ & $<10$ & $<10$ & $<10$ & $<10$ & 141 \\
\hline $\bar{y}-n$ itrosodime thylamine & $<10$ & $<10$ & $<10$ & $<10$ & $<10$ & $<10$ & $<10$ \\
\hline Benzidine & $<50$ & $<50$ & $<50$ & $<50$ & $<50$ & $<50$ & $<50$ \\
\hline 1.2-0iphenylhydrazine & $<20$ & $<20$ & $<20$ & $<20$ & $<20$ & $<20$ & $<20$ \\
\hline Aidrin & $<10$ & $<10$ & $<10$ & $<10$ & $<10$ & $<10$ & $<10$ \\
\hline oleldrin & $<10$ & $<10$ & $<10$ & $<10$ & $<10$ & $<10$ & $<10$ \\
\hline Chlordane & $<10$ & $<10$ & $<10$ & $<10$ & $<10$ & $<10$ & $<10$ \\
\hline $4.4^{\prime}-0 D T$ & $<10$ & $<10$ & $<10$ & $<10$ & $<10$ & $<10$ & $<.10$ \\
\hline $4.4^{\prime}-D O E$ & $<10$ & $<10$ & $<10$ & $<10$ & $<10$ & $<10$ & $<10$ \\
\hline $4.4^{\prime}-000$ & $<10$ & $<10$ & $<10$ & $<10$ & $<10$ & $<10$ & $<10$ \\
\hline Endosulfan I & $<10$ & $<10$ & $<10$ & $<10$ & $<10$ & $<10$ & $<10$ \\
\hline Endosulfan II & $<10$ & $<10$ & $<10$ & $<10$ & $<10$ & $<10$ & $<10$ \\
\hline Endosulfan sulfate & $<10$ & $<10$ & $<10$ & $<10$ & $<10$ & $<10$ & $<10$ \\
\hline Antline & $<10$ & $<10$ & $<10$ & $<10$ & $<10$ & $<10$ & $<10$ \\
\hline Benzyl a lcohol & $<10$ & $<10$ & $<10$ & $<10$ & $<10$ & $<10$ & $<10$ \\
\hline 2-Nitroantline & $<10$ & $<10$ & $<10$ & $<10$ & $<10$ & $<10$ & $<10$ \\
\hline 3-Nitroantline & $<10$ & $<10$ & $<10$ & $<10$ & $<10$ & $<10$ & $<10$ \\
\hline 4-Nitroantline & $<10$ & $<10$ & $<10$ & $<10$ & $<10$ & $<10$ & $<10$ \\
\hline Endrin & $<10$ & $<10$ & $<10$ & $<10$ & $<10$ & $<10$ & $<10$ \\
\hline Endrin a ldehyde & $<10$ & $<10$ & $<10$ & $<10$ & $<10$ & $<10$ & $<10$ \\
\hline Heptachlor & $<10$ & $<10$ & $<10$ & $<10$ & $<10$ & $<10$ & $<10$ \\
\hline Heptachlor epoxide & $<10$ & $<10$ & $<10$ & $<10$ & $<10$ & $<10$ & $<10$ \\
\hline Alpha-BHC & $<10$ & $<10$ & $<10$ & $<10$ & $<10$ & $<10$ & $<10$ \\
\hline Beta-BHC & $<10$ & $<10$ & $<10$ & $<10$ & $<10$ & $<10$ & $<10$ \\
\hline Gamma-BHC (I indane) & $<10$ & $<10$ & $<10$ & $<10$ & $<10$ & $<10$ & $<10$ \\
\hline Delta-BHC & $<10$ & $<10$ & $<10$ & $<10$ & $<10$ & $<10$ & $<10$ \\
\hline
\end{tabular}


Appendix B

RESULTS OF ANALYSES OF TRENCH WATER

SAMPLES FROM SWSA 6, 1989*

\footnotetext{
B. P. Spalding, Environmental Sciences Division, Oak Ridge National Lab., unpublished data, 1989.
} 


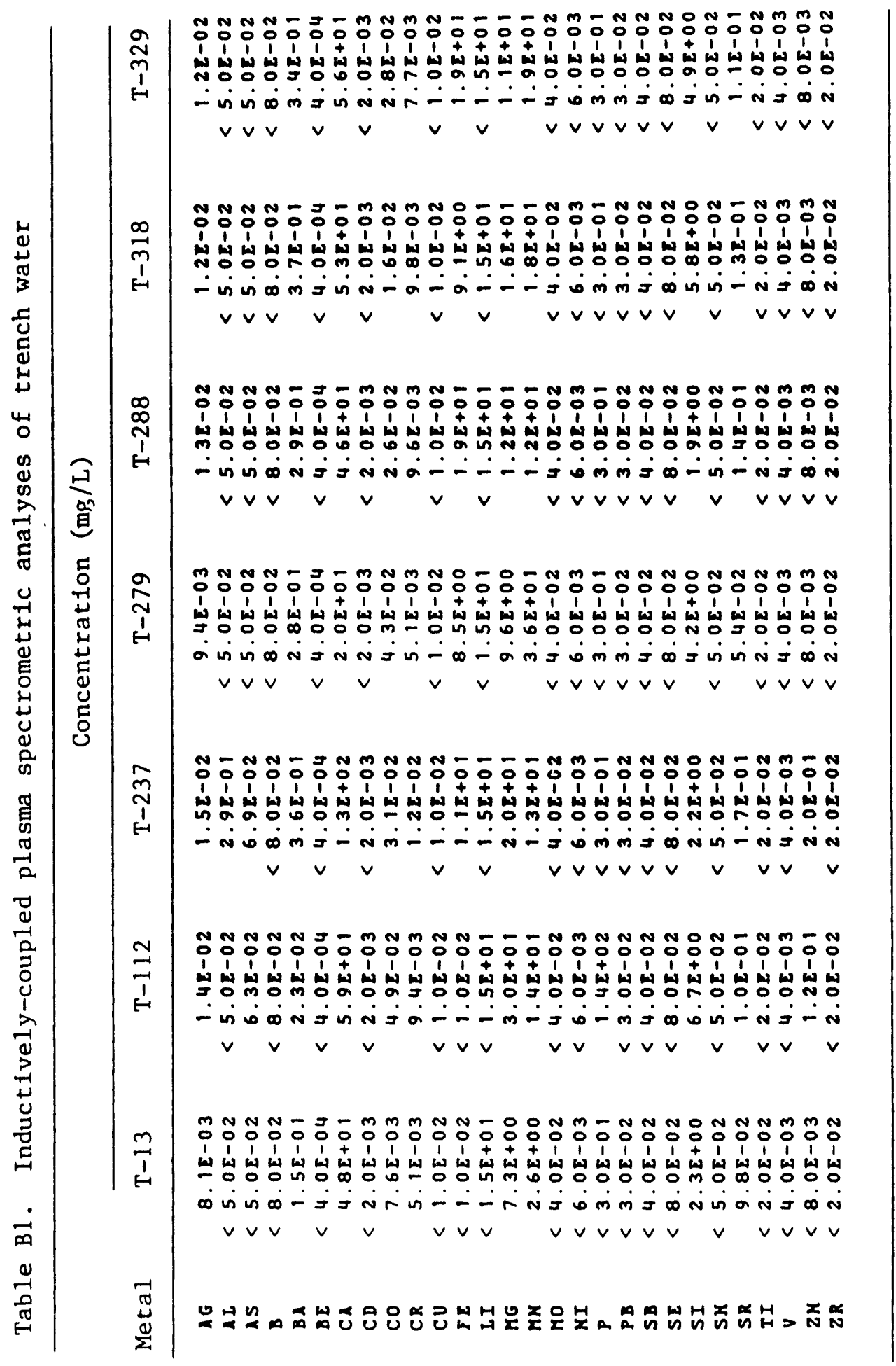




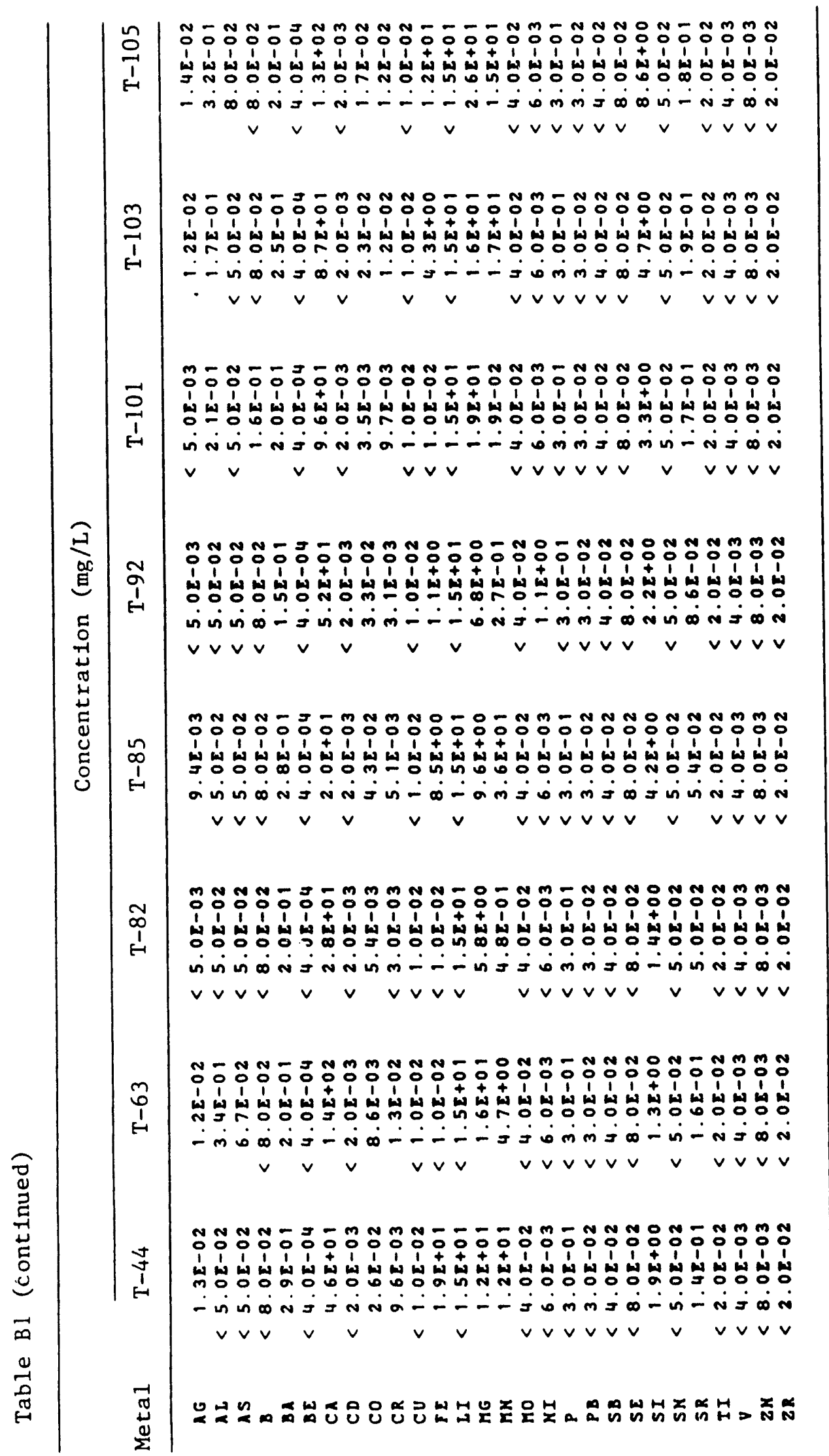


Table B2 Radionuclide analyses of trench water samples

\begin{tabular}{lcccc} 
& \multicolumn{4}{c}{ Radionuclide concentration (Bq/L) } \\
\cline { 2 - 5 } Trench & ${ }^{60} \mathrm{Co}$ & ${ }^{137} \mathrm{Cs}$ & ${ }^{90} \mathrm{Sr}$ & Tritium \\
\hline T-13 & $<2.0$ & 2.7 & 5.5 & 11,000 \\
T-44 & $<2.0$ & 4.4 & 1.0 & 970 \\
T-63 & $<2.0$ & 6.3 & 2.0 & 150 \\
T-82 & $<2.0$ & 12. & 660. & 32 \\
T-85 & $<2.0$ & 7.7 & 3.3 & 860 \\
T-92 & $<2.0$ & 2.6 & 0.9 & 880 \\
T-101 & $<2.0$ & $<2.0$ & 0.4 & 1,200 \\
T-105 & $<2.0$ & 4.7 & 0.8 & 1,800 \\
T-112 & $<2.0$ & 27. & 0.8 & 2,700 \\
T-180 & $<2.0$ & 3.5 & 1.5 & 470 \\
T-237 & $<2.0$ & 2.4 & 0.1 & 2,700 \\
T-279 & $<2.0$ & 36. & 35. & 950 \\
T-288 & $<2.0$ & 1.5 & 14. & 250 \\
T-318 & $<2.0$ & $<2.0$ & 0.04 & 1,500 \\
T-329 & $<2.0$ & $<2.0$ & 0.8 & 99 \\
\hline & & & &
\end{tabular}


m

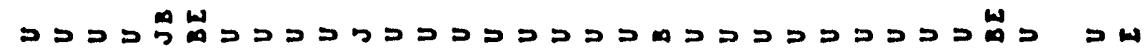

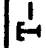

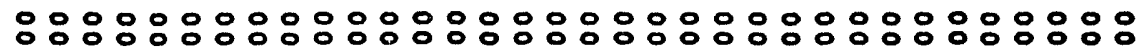

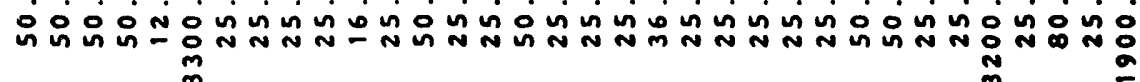

ニニニニニニニニニニニニニニニニニニニニニニニニニニニニニニニニニュニン

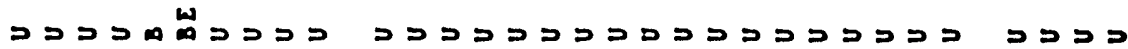

$\infty$

$\stackrel{n}{1}$

- - - - - - -

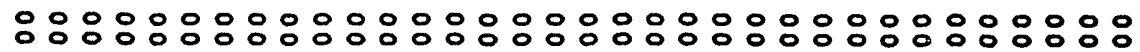

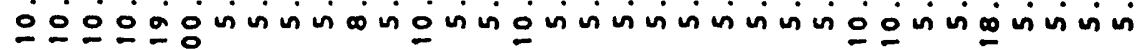
:

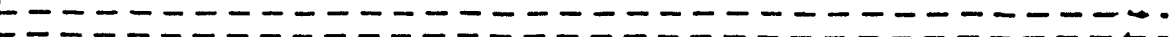

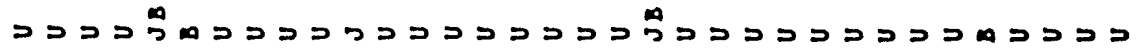

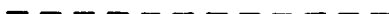

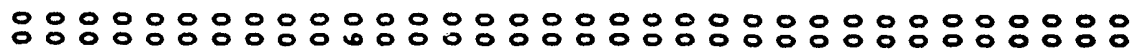

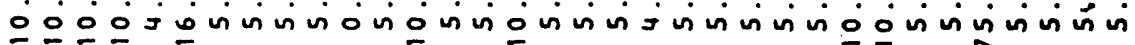

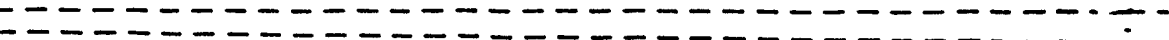

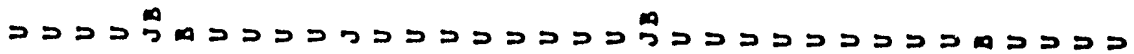

--- - - - - - - - - - - - - - - - - - - - - -

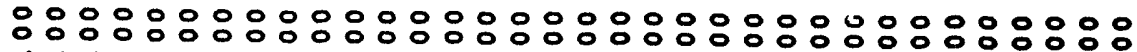
is 


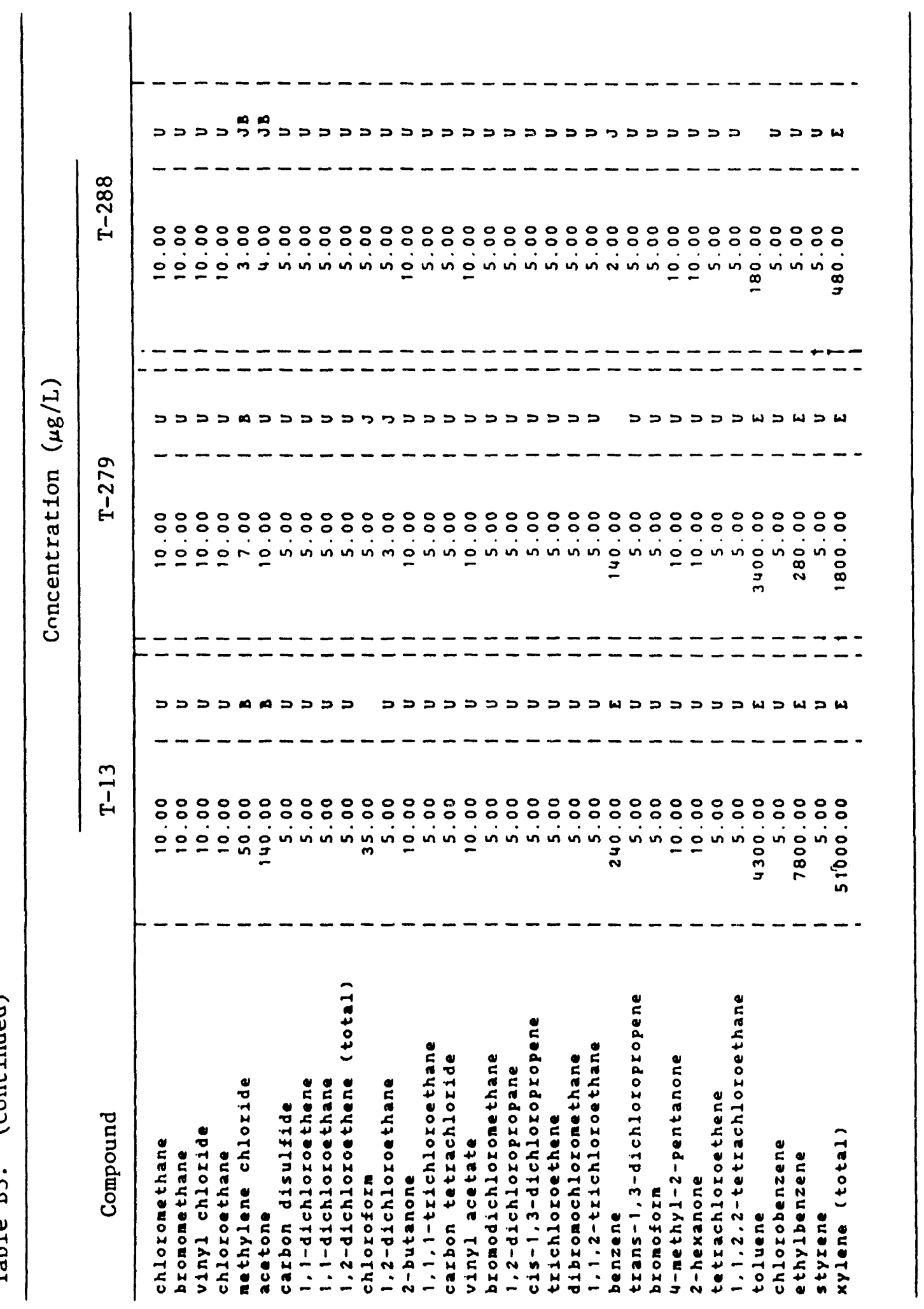




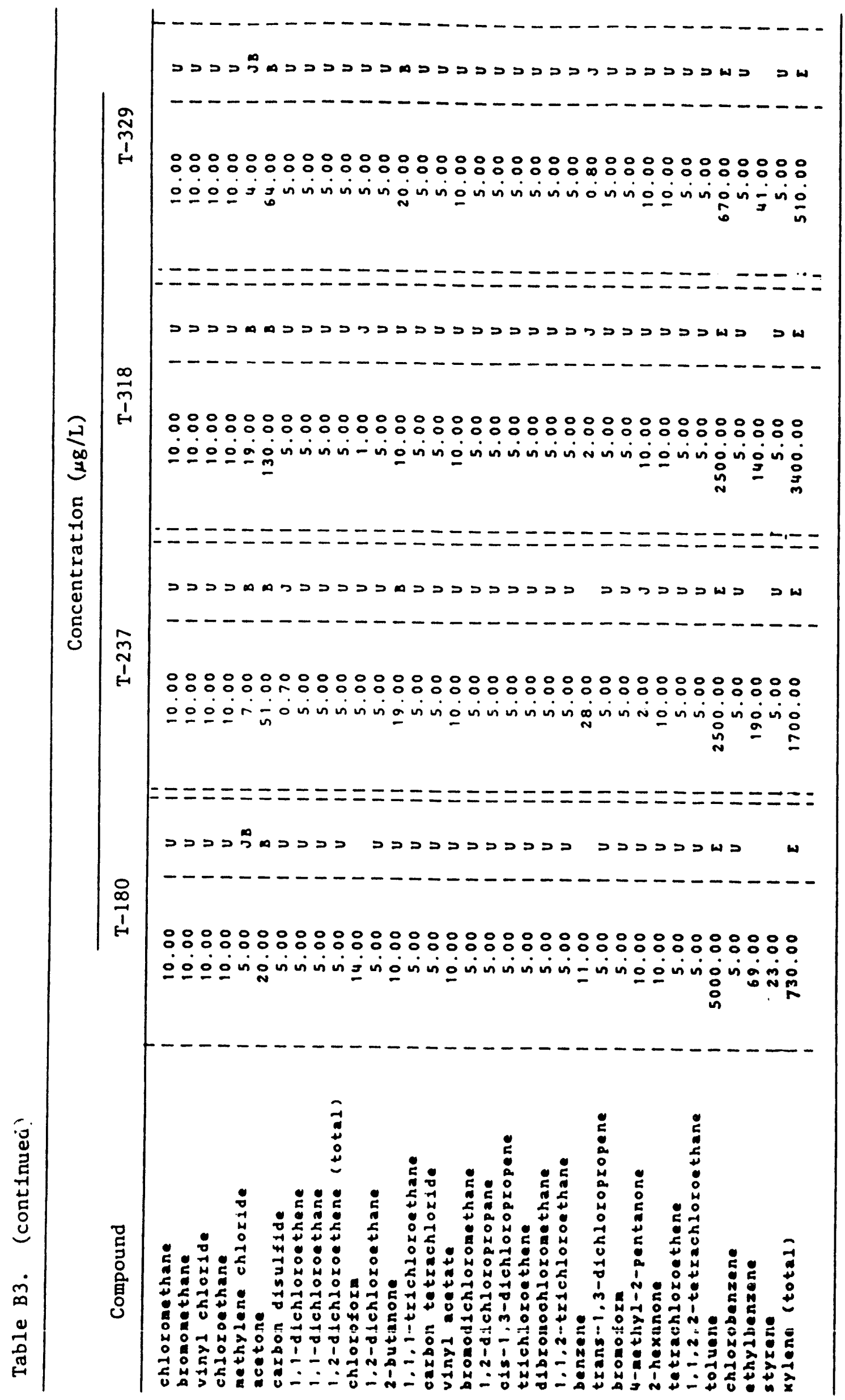




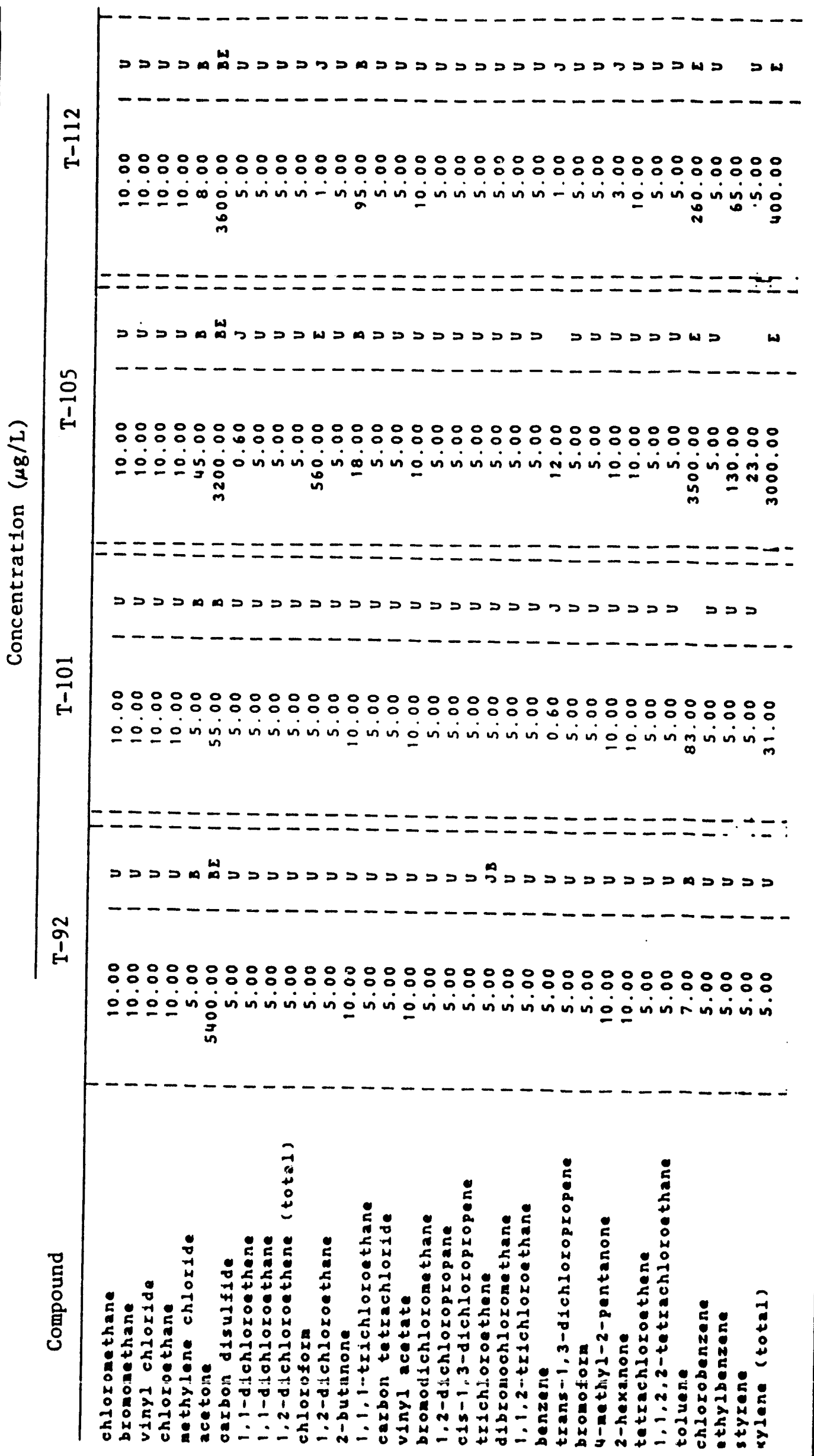




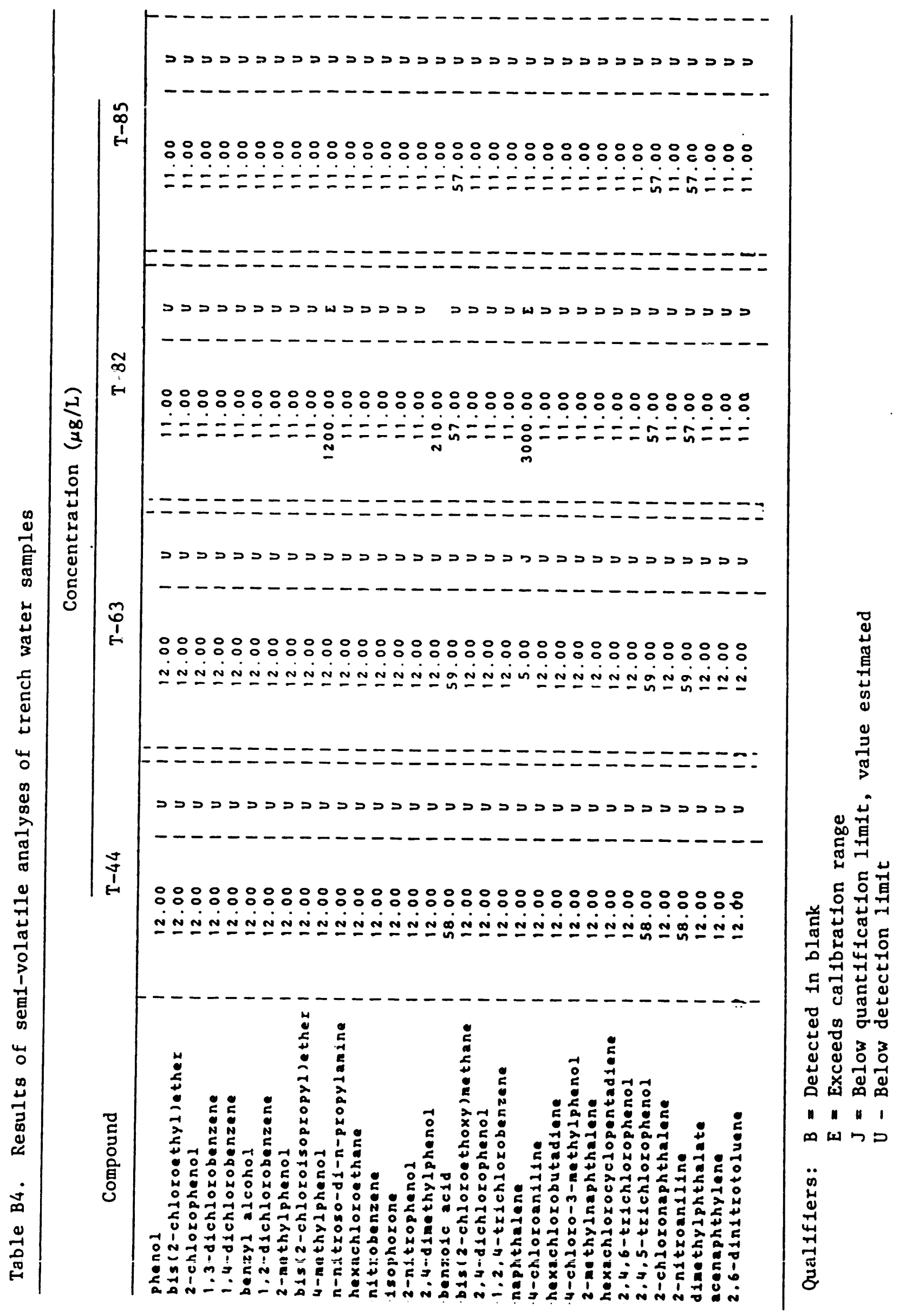




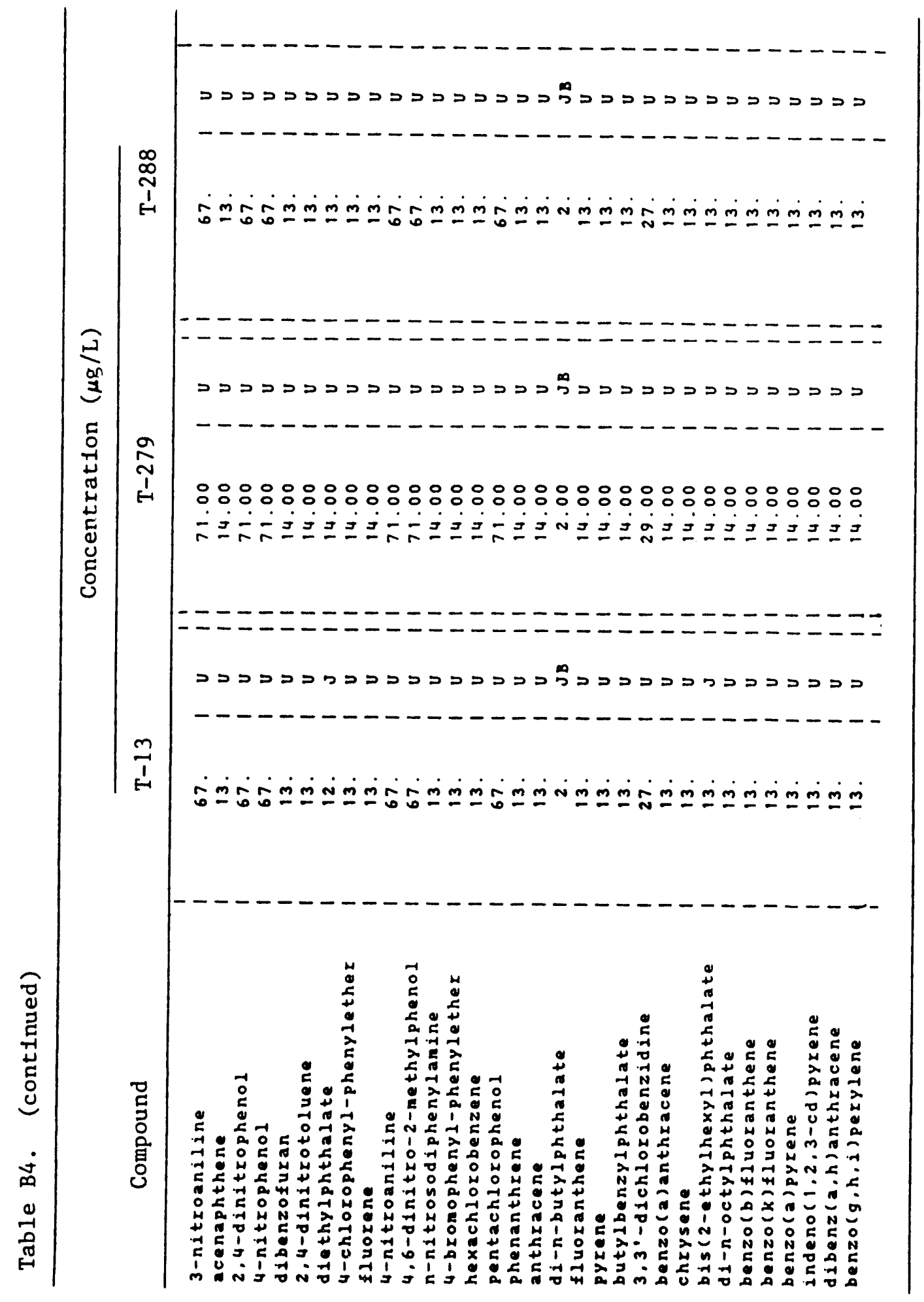




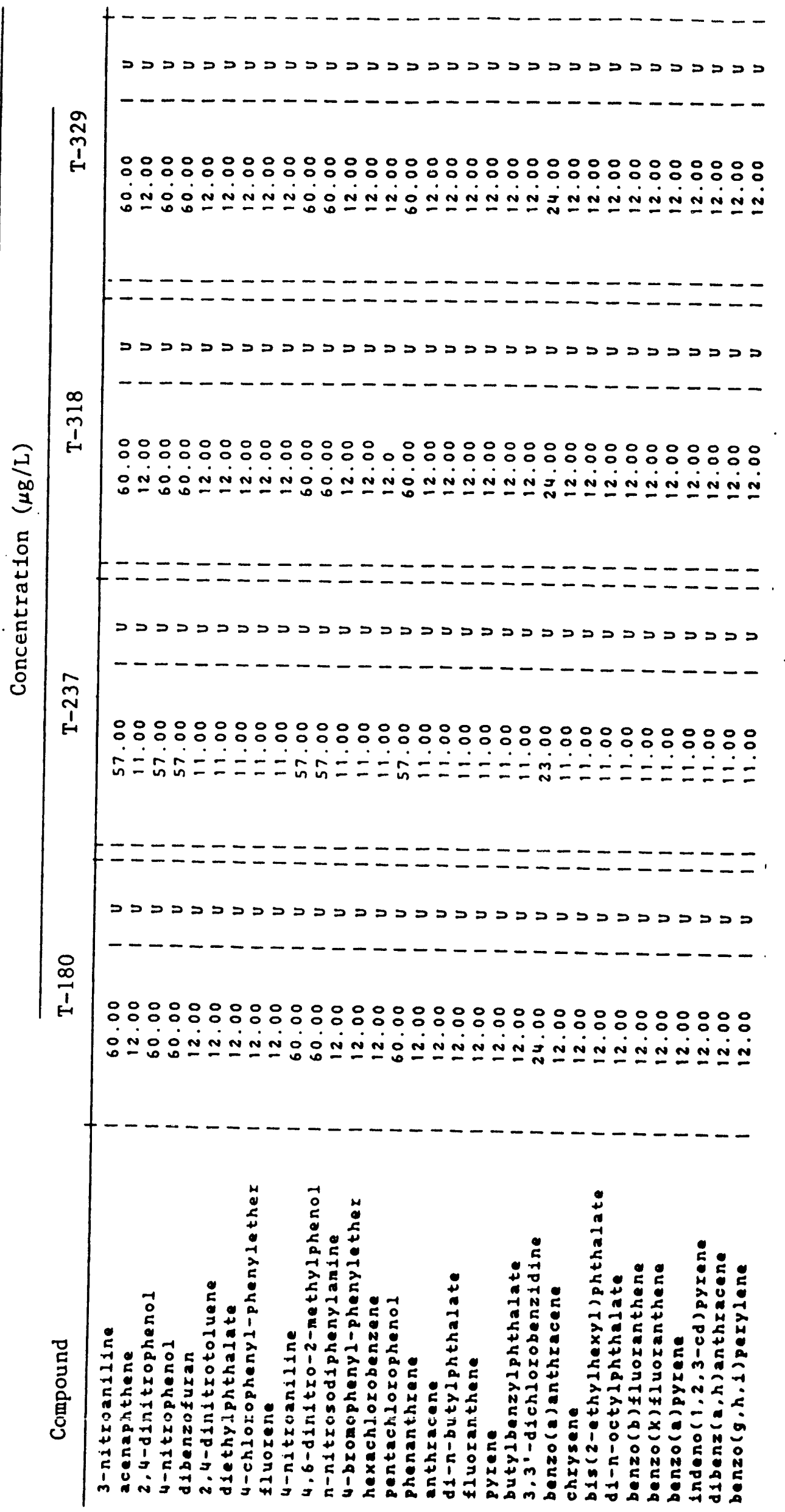




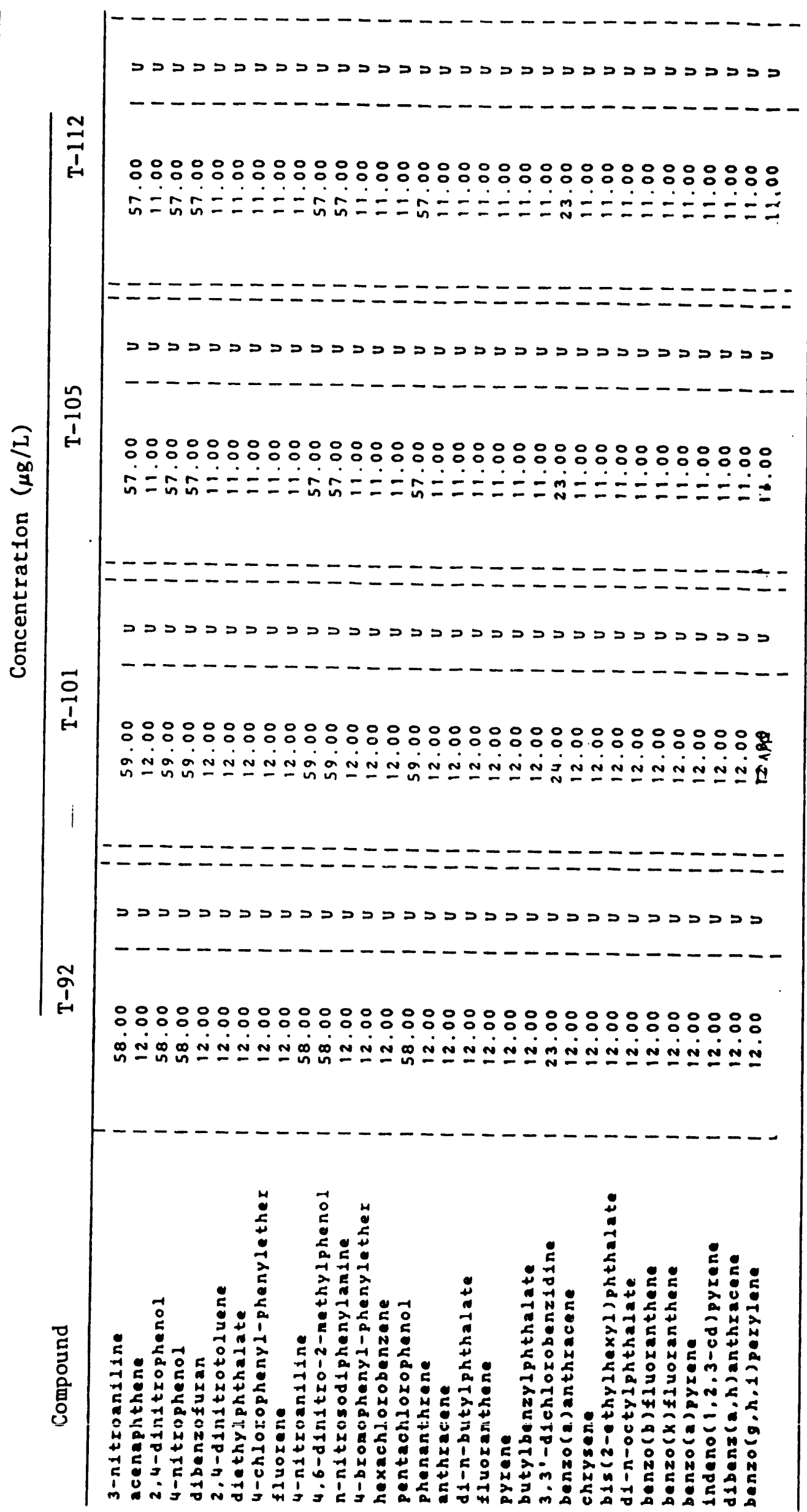




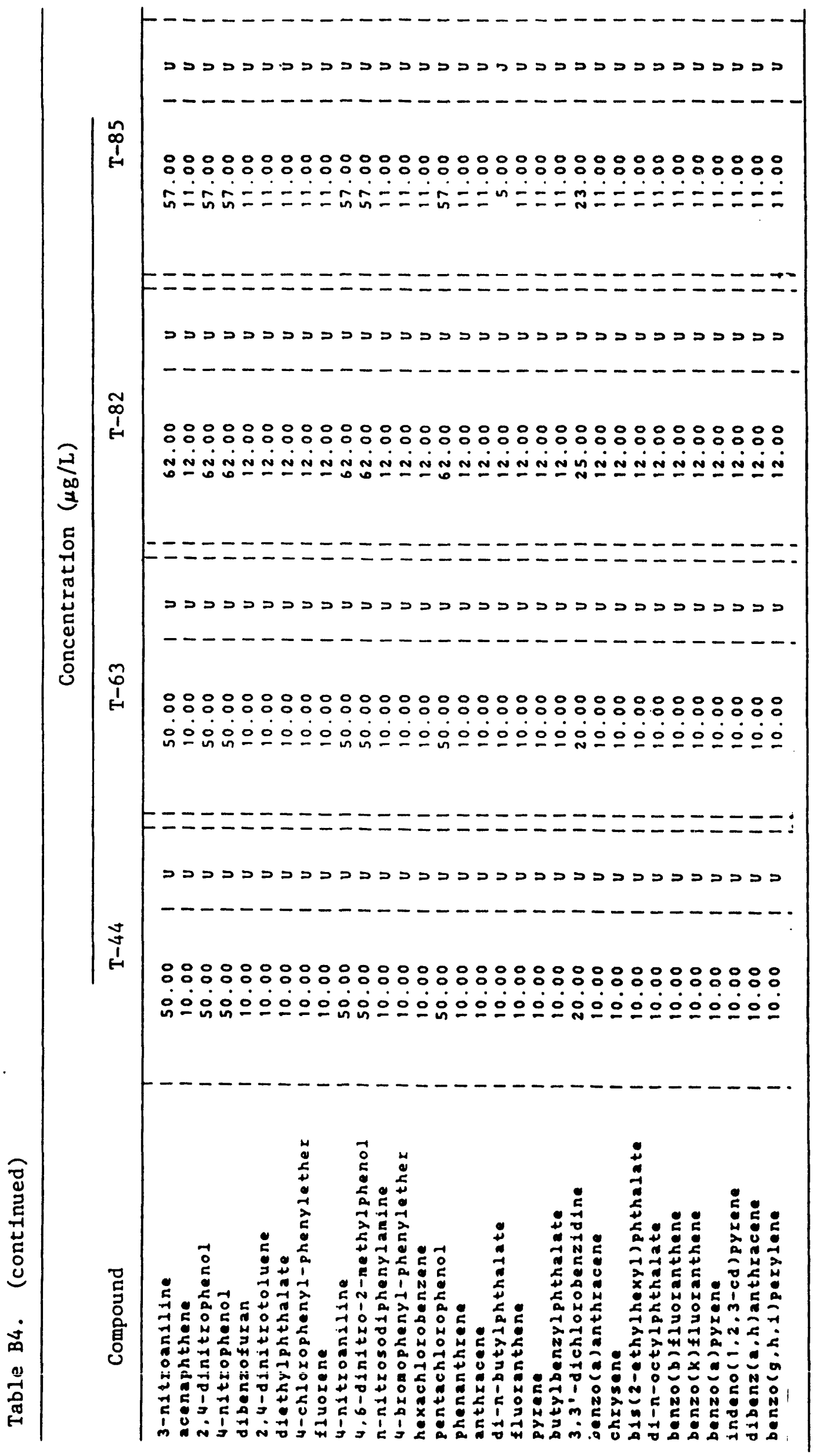




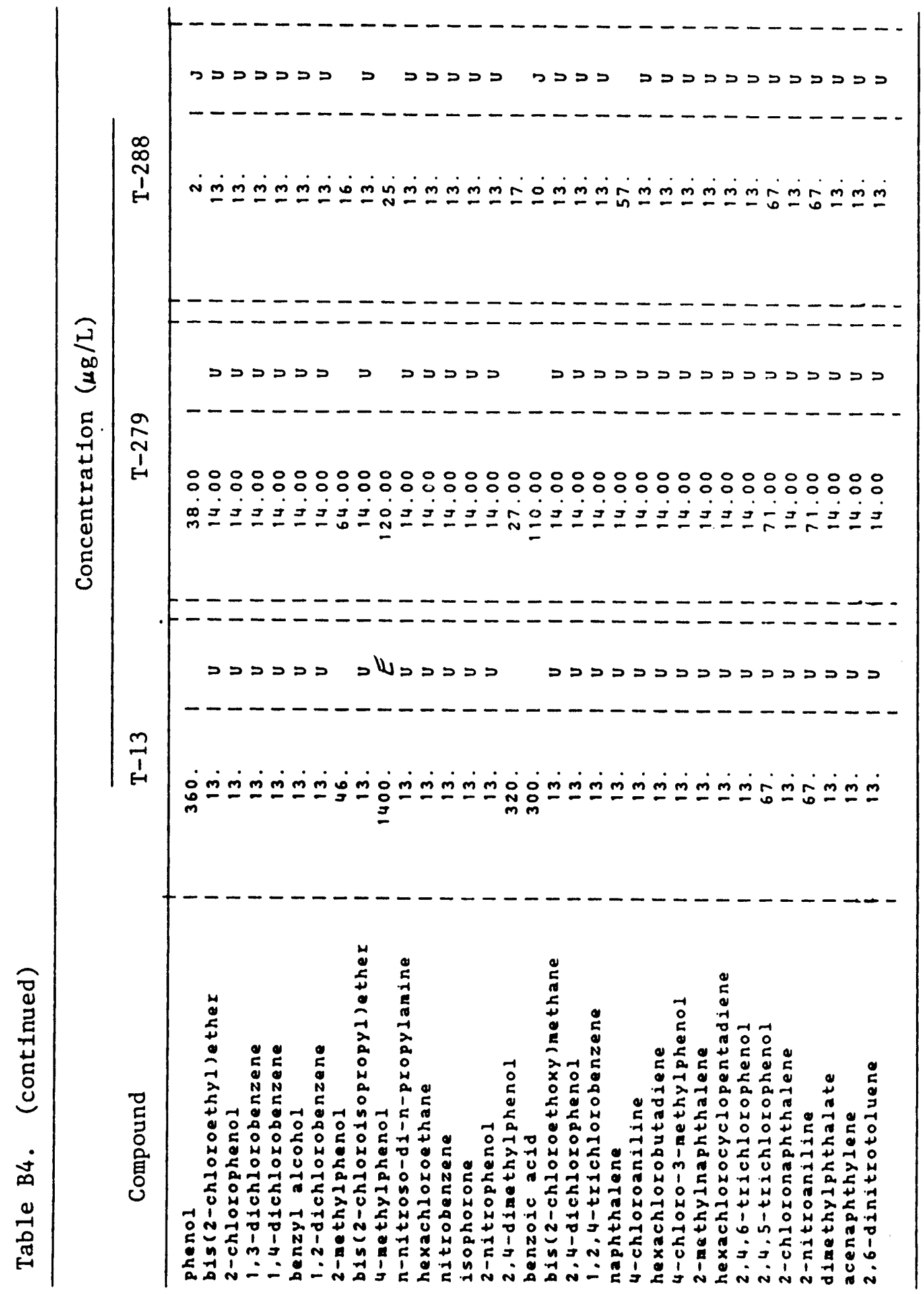




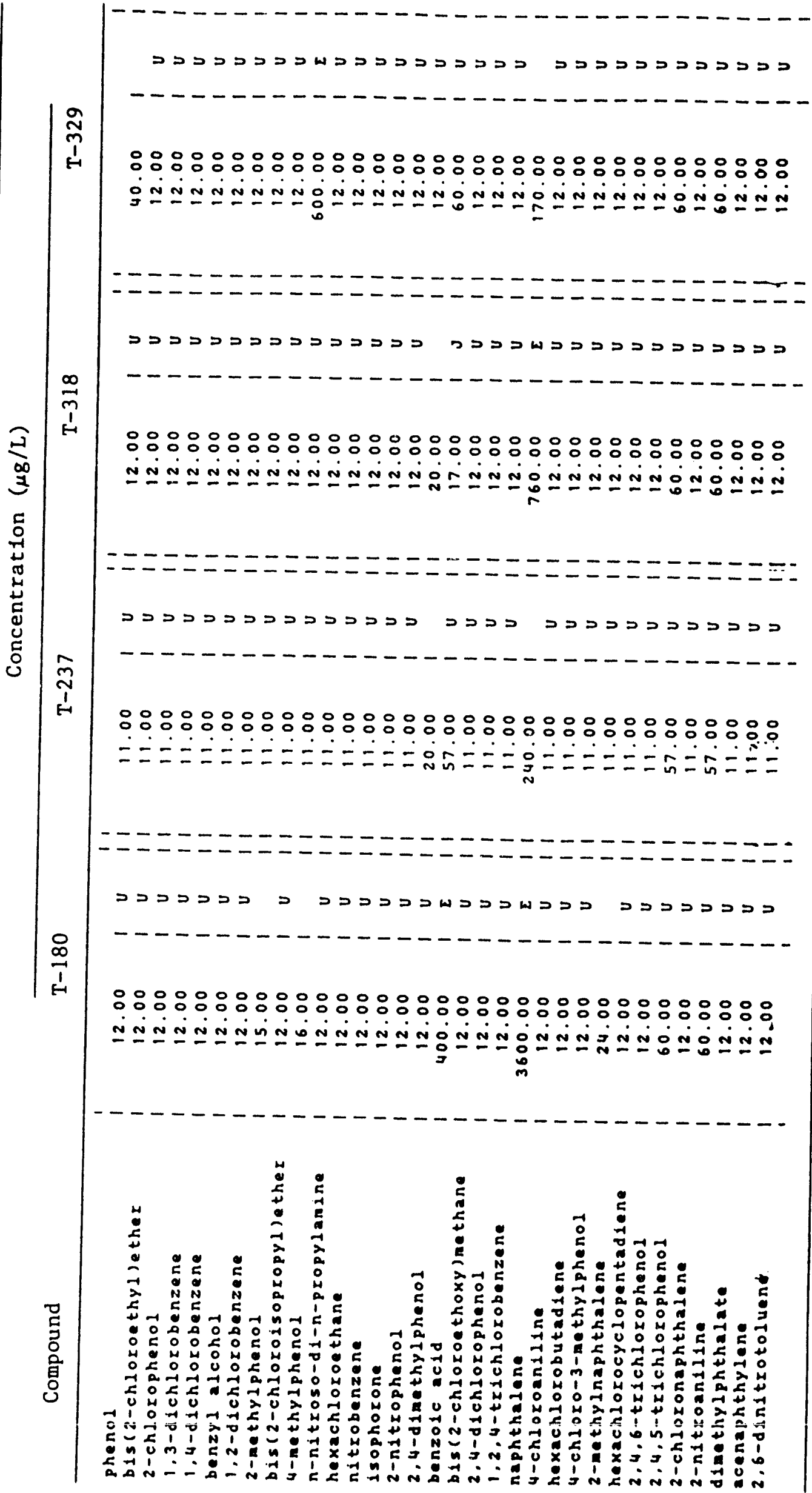




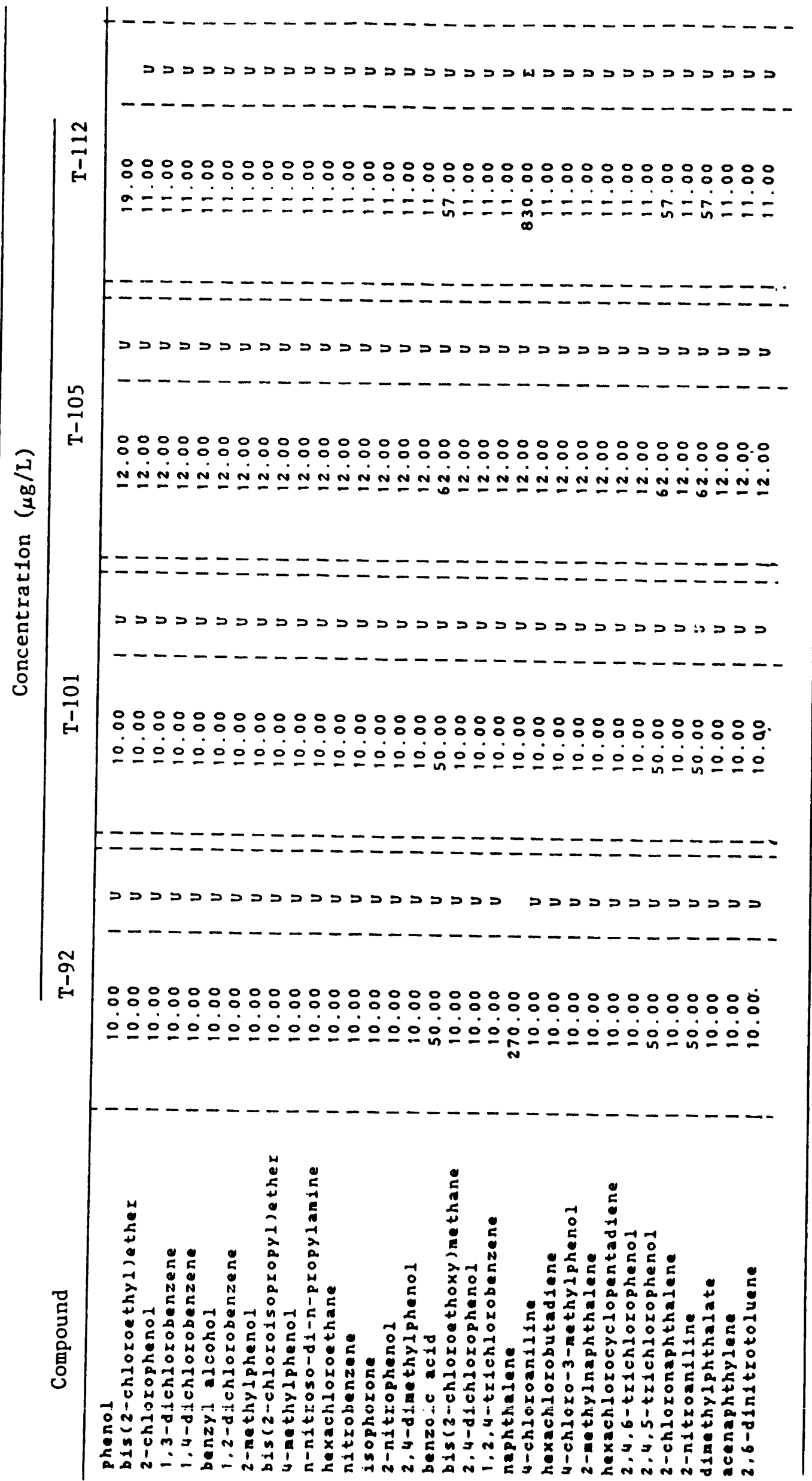


Appendix C

RESULTS OF VOLATILE AND SEMIVOLATILE ANALYSES OF

INITIAL TRENCH WATER SAMPLES NOVEMBER 10, 1989 


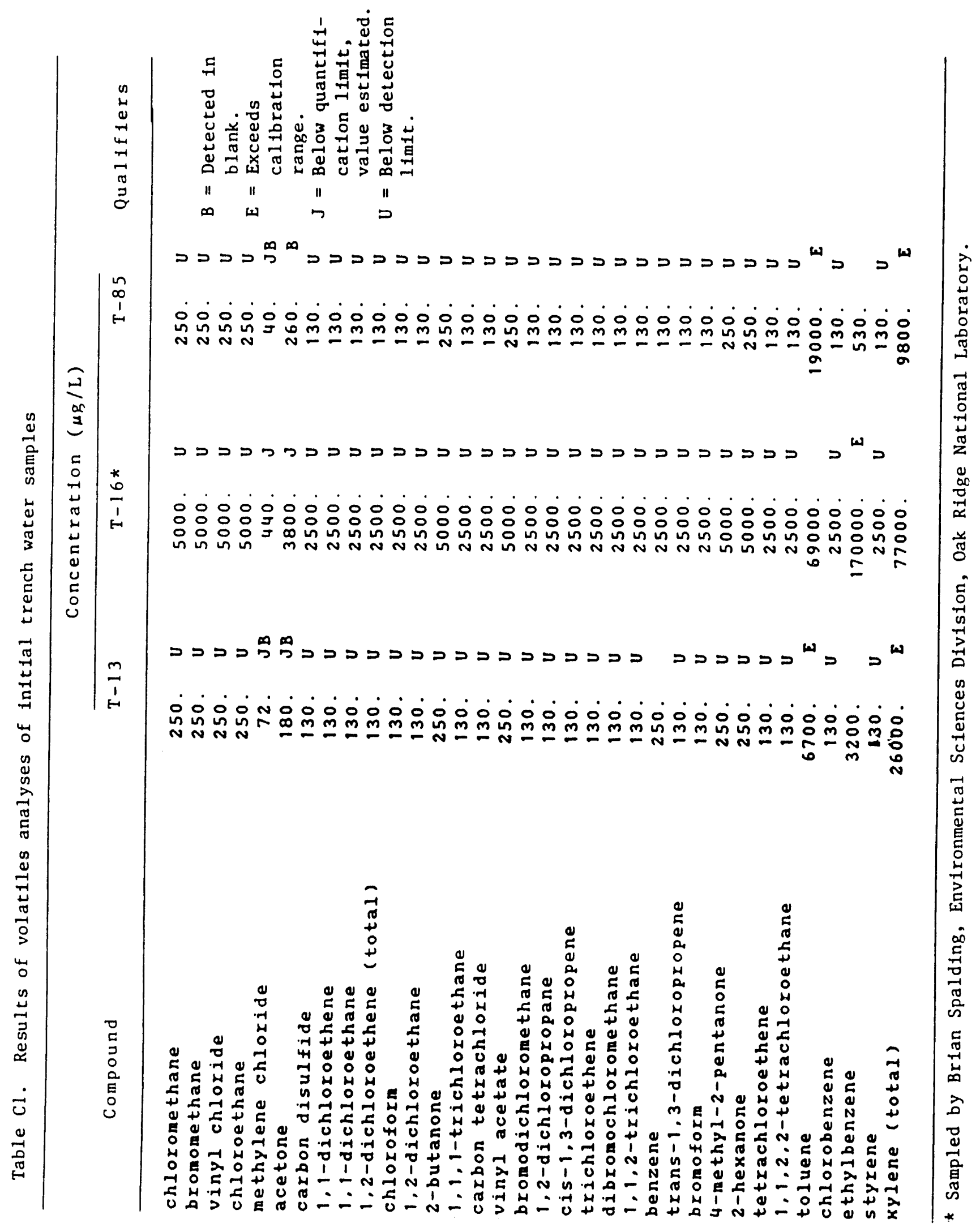




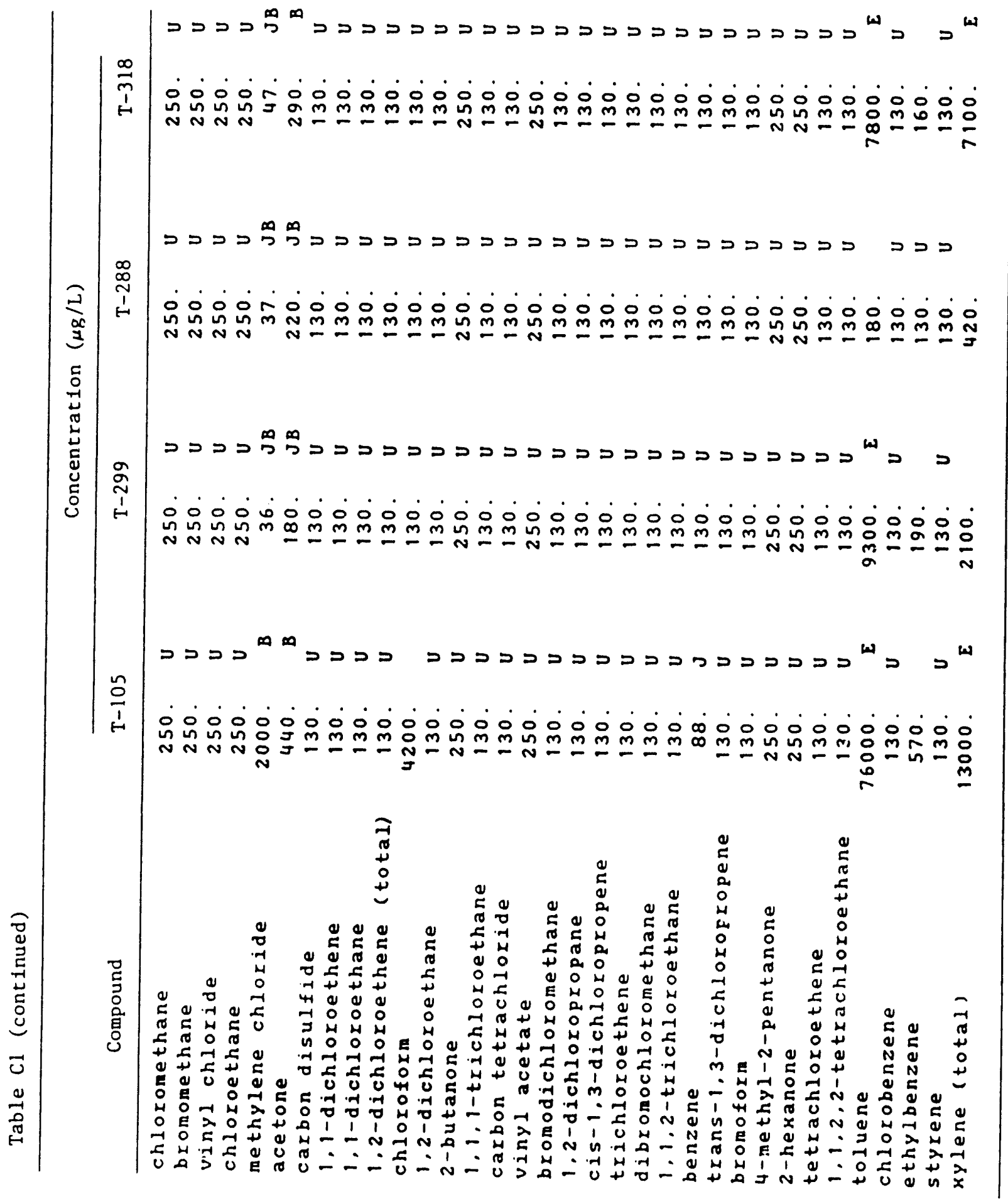




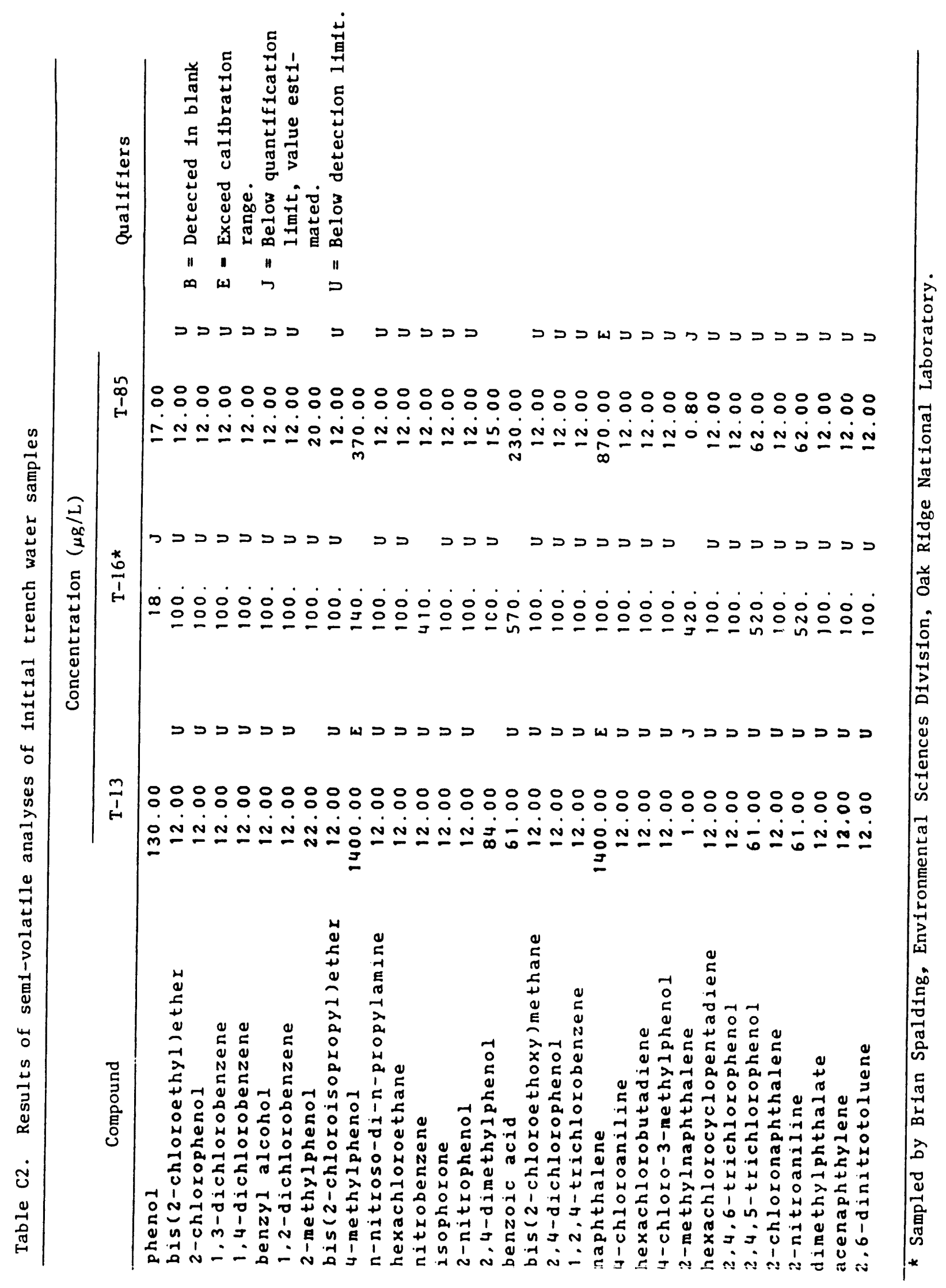




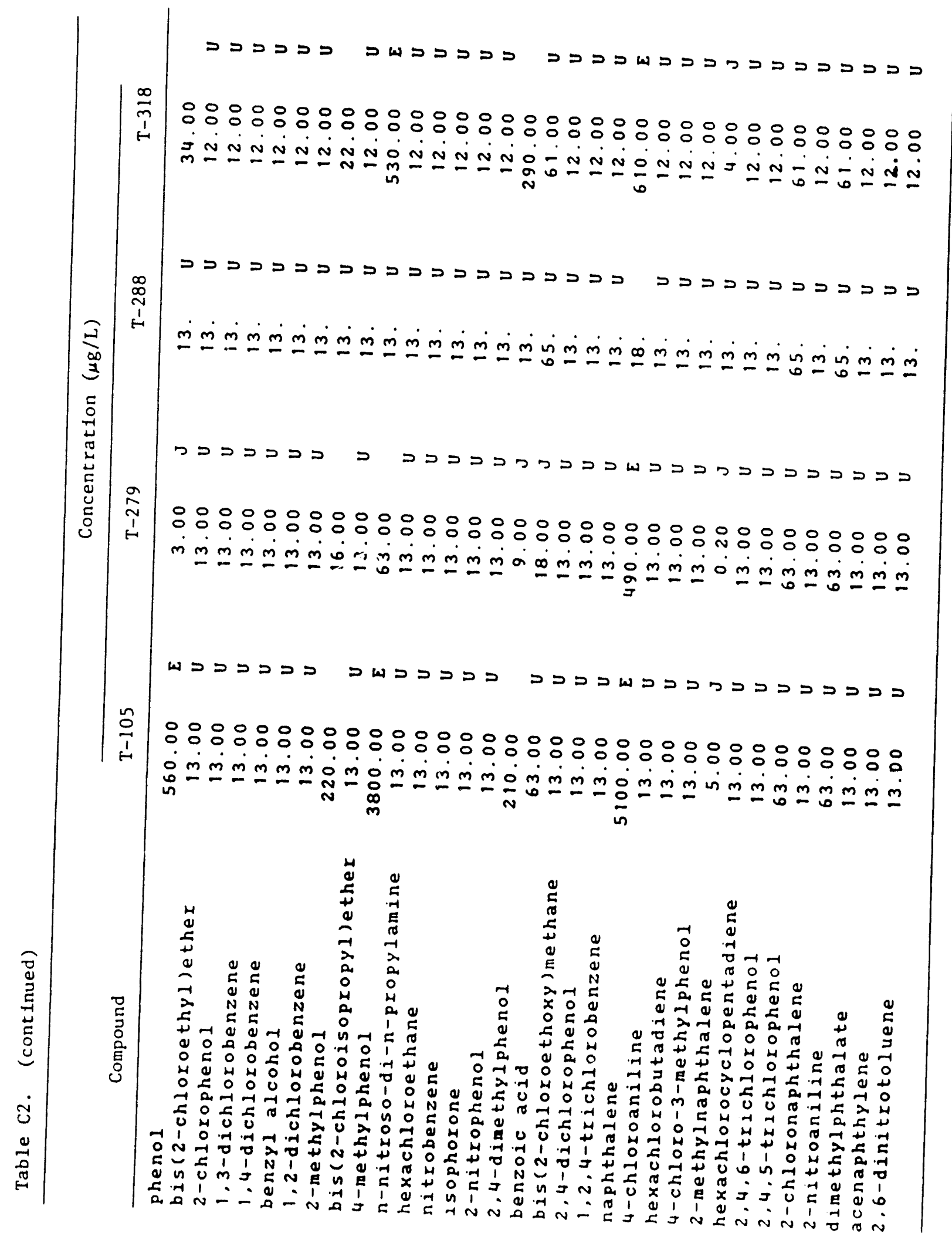




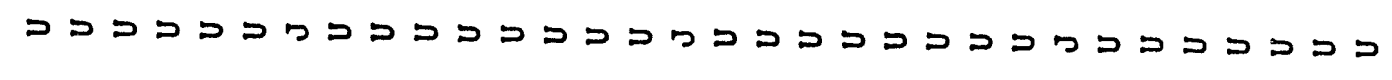

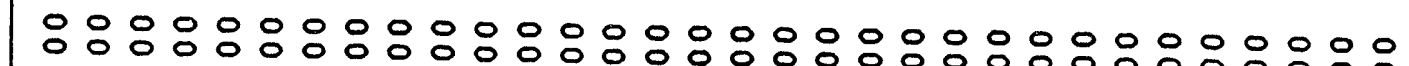

in $\dot{n}$ n

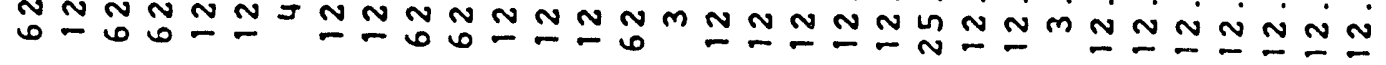

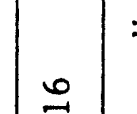

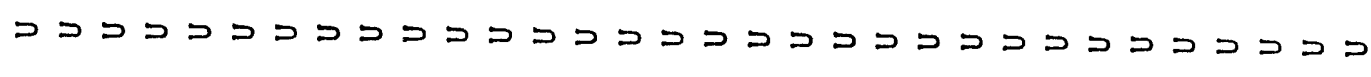

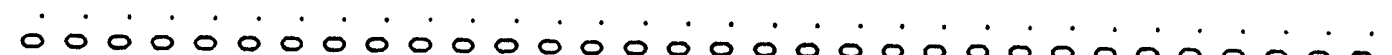

in

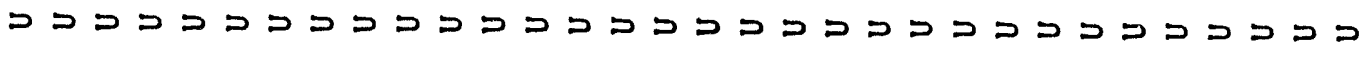

$\underset{m}{m}$

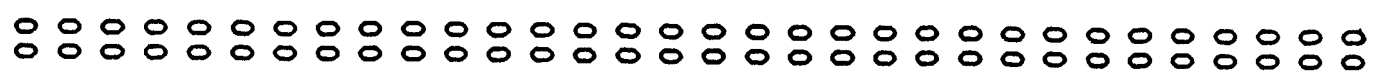
ด +

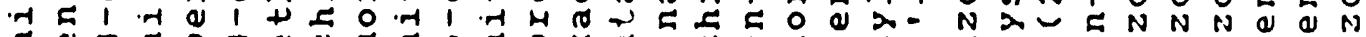

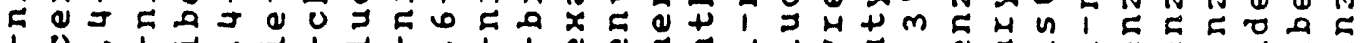

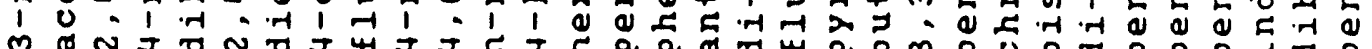




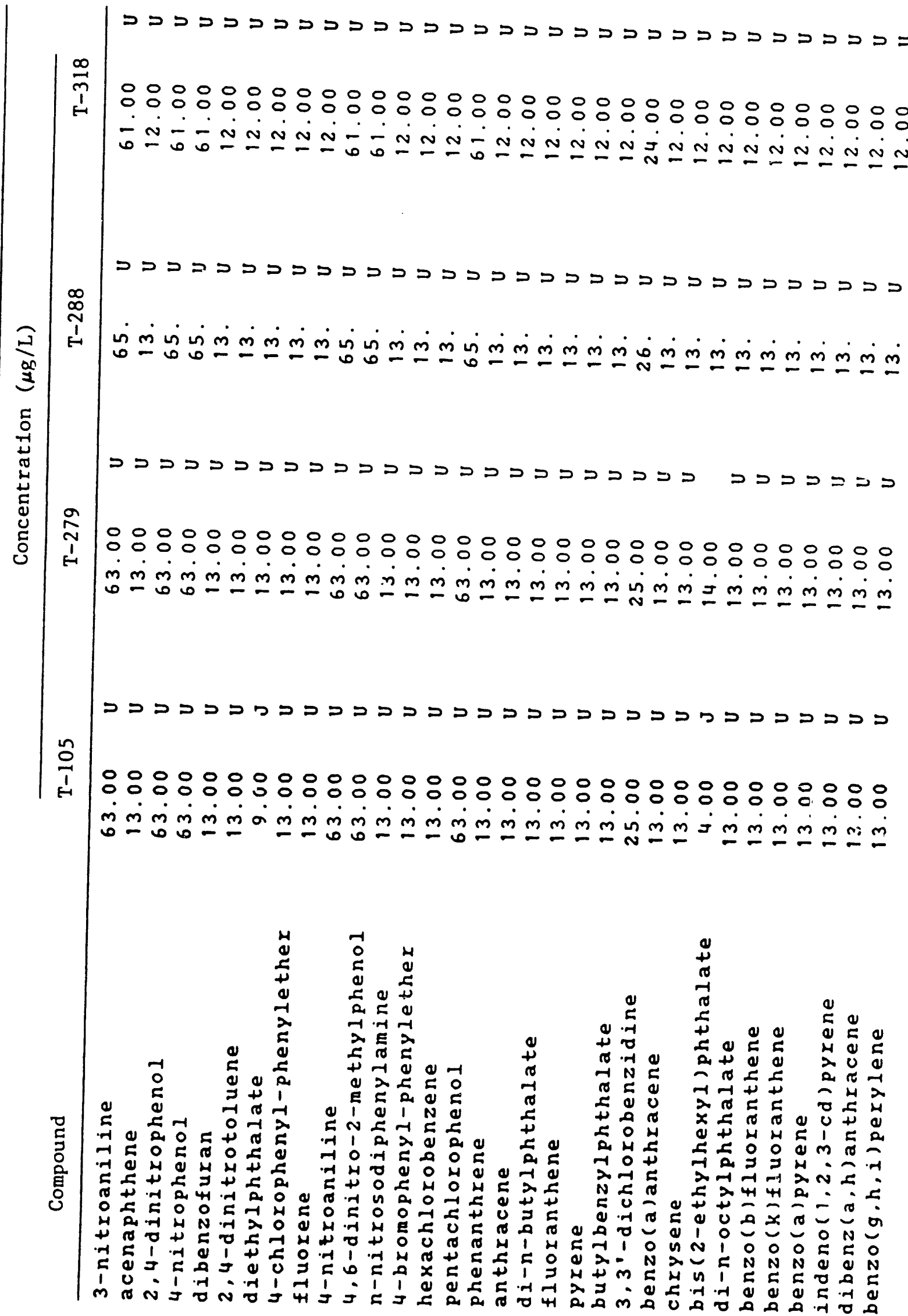


Appendix D

RESULTS OF ANALYSES OF TREATED WATER

FROM TRENCHES T-13, T-16, T-41 AND T-105 


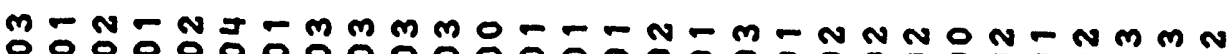

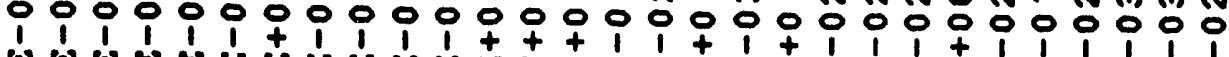

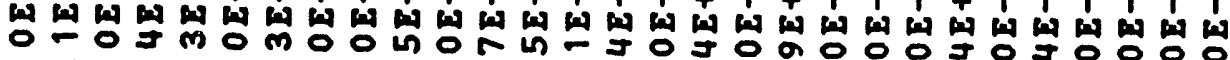

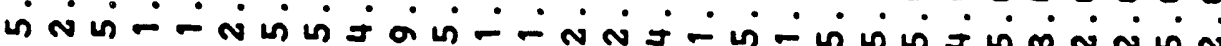
$\checkmark v$

$$
\checkmark
$$$$
\vee v
$$$$
\checkmark
$$

$\checkmark$

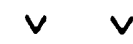

$\checkmark \vee V \vee$

$\vee \vee \vee \vee$

1
0,0
0

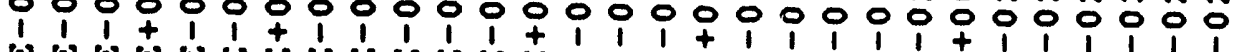

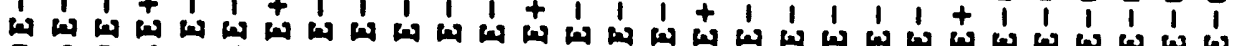
○

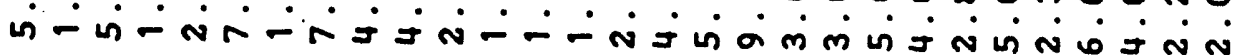

$\sqrt{2}$

$\vee v \vee \quad v$

$\vee v \vee v \vee v v v$

$\checkmark v$

mi i i i i

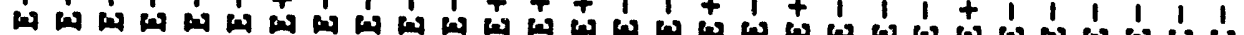

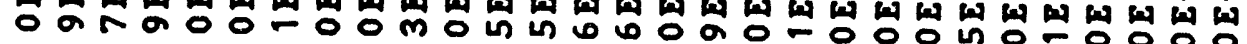
O O. O O O O un 0 - N N 0 in J 0 in $\checkmark$ $\checkmark v \vee v \vee$

$$
\checkmark
$$

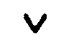

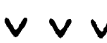
$\checkmark \vee v \vee v$ (1)

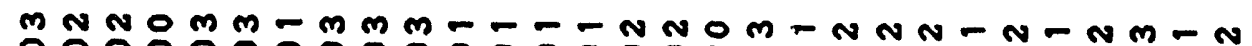

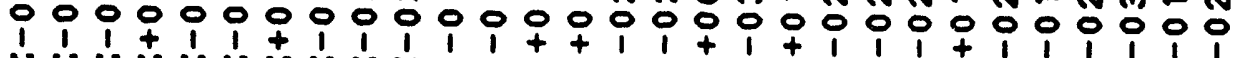
w $\omega^{+}$ \% ㅇㅇㅇㅇㅇㅇ

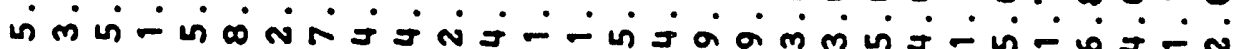
$\vee v \vee v \vee v \vee v \vee v \vee v \vee v v$

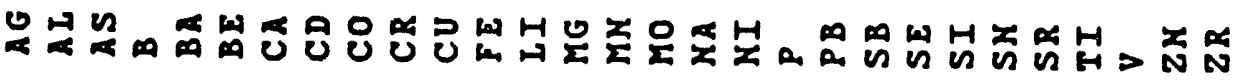




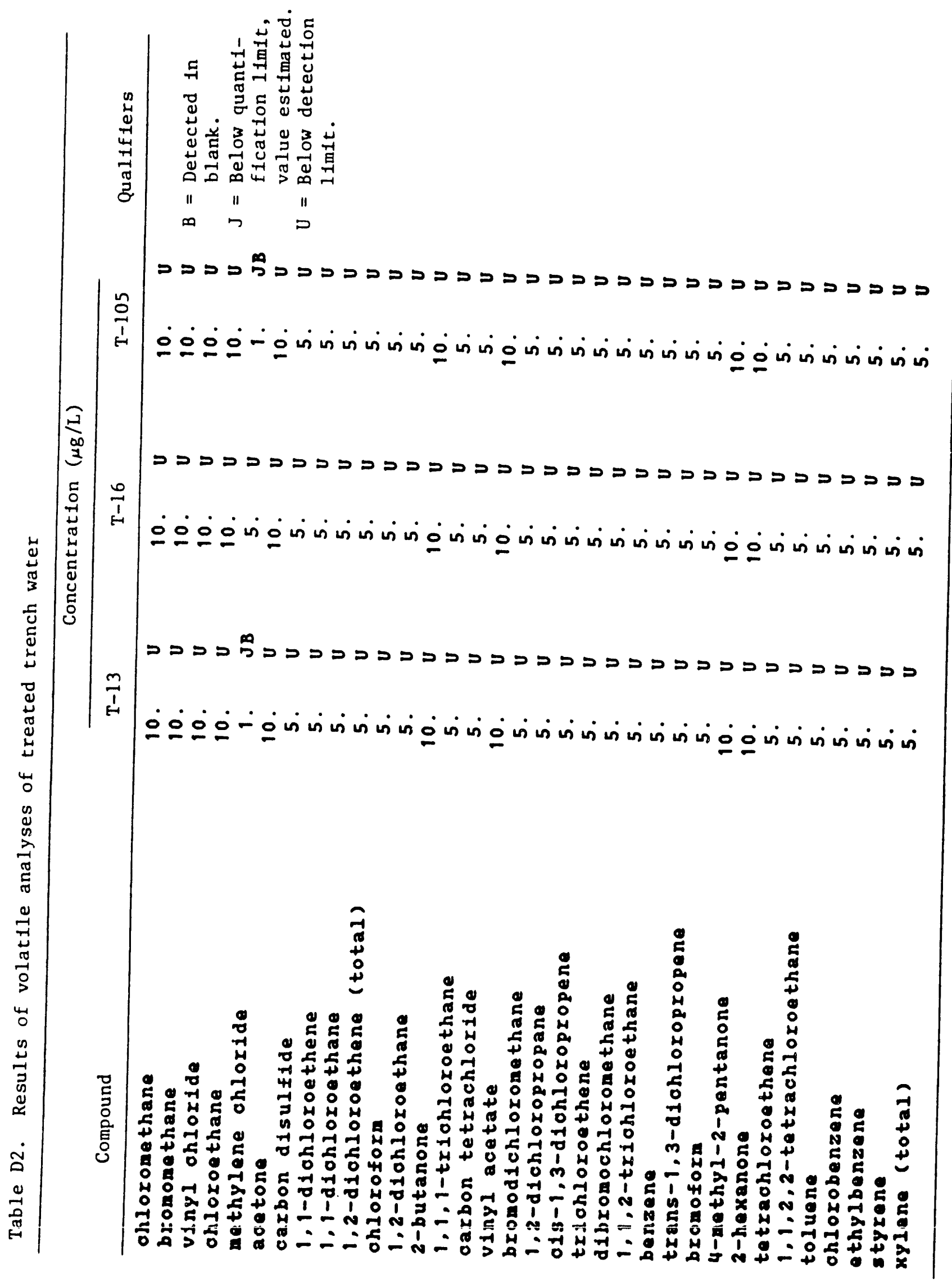




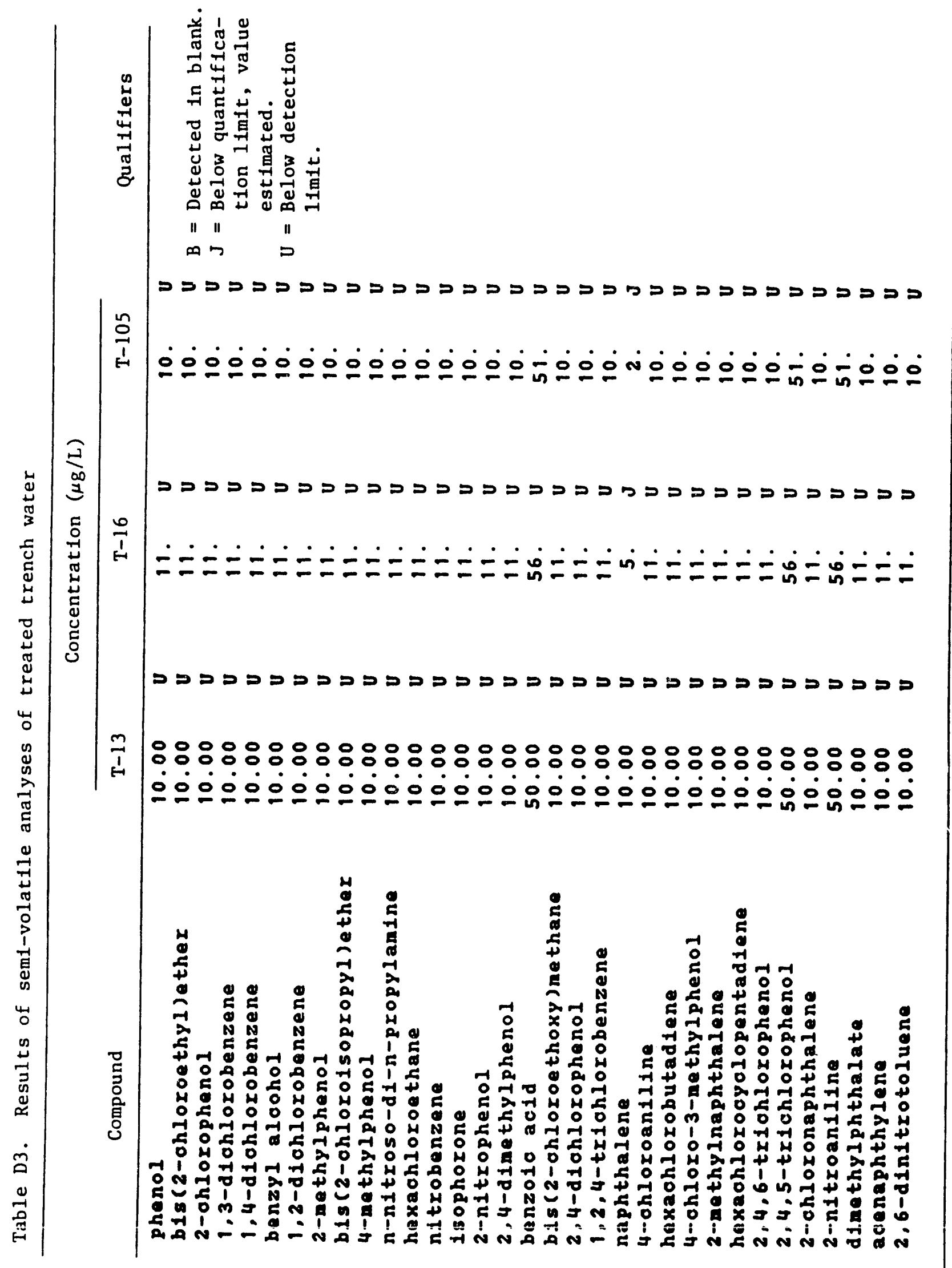




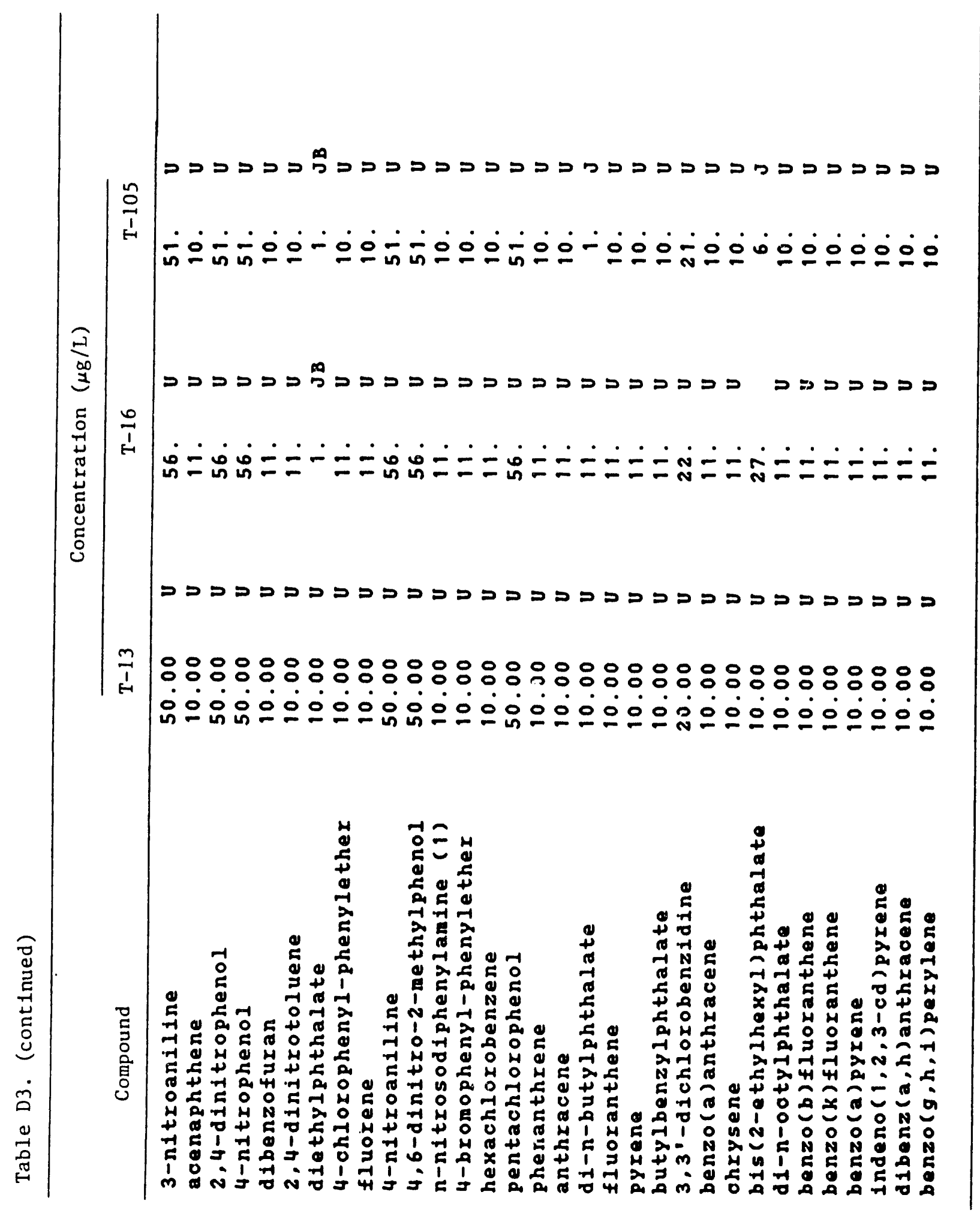




\section{DISTRIBUTION}

1. L. V. Asplund/N. W. Durfee

2. L. D. Bates

3. C. H. Brown

4. C. Clark

5. J. S. Colley

6. K. W. Cook

7-9. S. B. Garland II

10. C. D. Goins

11. D. D. Huff

12. L. D. Hyde

13. K. H. King

14. A. J. Kuhaida

15. C. P. Manrod

16. L. E. McNeese

17. C. E. Nix

18-19. P. T. Owen

20. S. M. Robinson

21. G. E. Rymer

22. T. F. Scanlan

23. P. A. Schrandt

24. B. P. Spalding

25. M. G. Stewart

26. D. W. Swindle

27-28. P. A. Taylor

29. D. D. Van Hoesen

30. L. D. Voorhees

31. G. E. Ward

32. R. K. White

33. A. S. Will

34. Central Research Library

35-36. Laboratory Records Dept.

37. ORNL Patent Section

38-42. ER Document Management Center

43. Office of Assistant Manager for Energy Research and Development, DOE Field Office, Oak Ridge, P.O. Box 2001, Oak Ridge, TN 37831-8600

44. P. H. Edmonds, Radian Corporation, 120 South Jefferson Circle, Oak Ridge, TN 37830

45-46. J. R. Kannard, Program Manager, Bechtel National, Inc., P.O. Box 350, Oak Ridge Corporate Center, 151 Lafayette Drive, Oak Ridge, TN 37830

47-50. W. E. Murphie, Department of Energy, Office of Environmental Restoration, Eastern Area D\&D Branch, EM-423 (GTN), Washington, DC 20545

51-52. S. S. Perkins, DOE Field Office, Oak Ridge, Information Resource Center, Administrative Record File, 105 Broadway, Oak Ridge, TN 37830

53-54. S. P. Riddle, DOE Field Office, Oak Ridge, P.O. Box 2001, Oak Ridge, TN 37831-8541

55-56. R. C. Sleeman, DOE Field Office, Oak Ridge, P.O. Box 2001, Oak Ridge, TN 37831-8541

57-58. Off:ce of Scientific and Technical Information, P.O. Box 62, Oak Ridge, TN 37831 

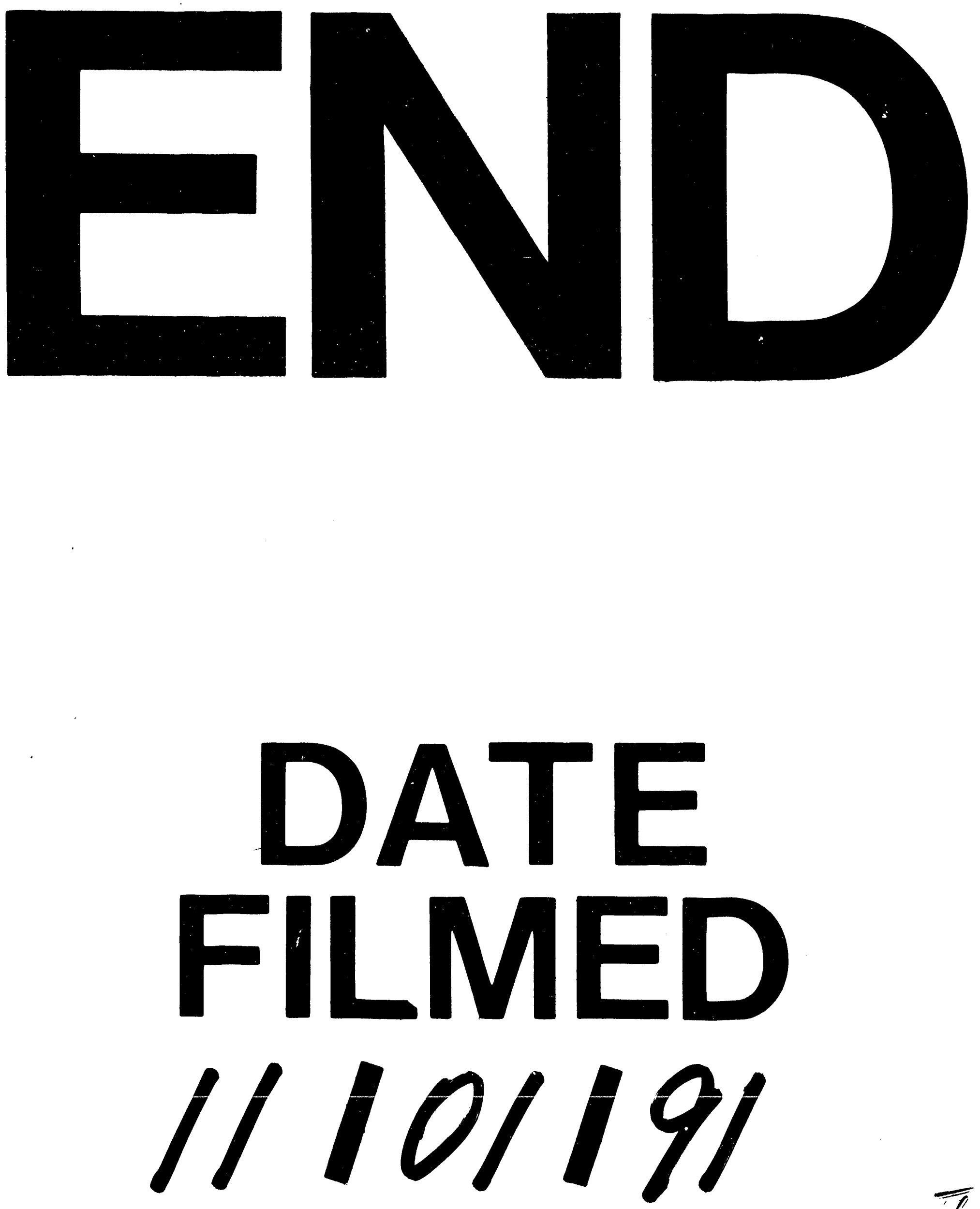

I 
